Revista do Programa de Pós-Graduação em Artes da

Cena, Universidade Estadual de Campinas

Performing Arts Graduate Program Journal, University of

Campinas

\title{
O diferencial da atuação de um licenciado em dança na construção da autonomia dos alunos em diferentes realidades
}

The differential of the performance of a licensed in dance in the construction of the autonomy of the students in different realities

\author{
Paula Caruso Teixeira ${ }^{1}$ \\ Angélica Duarte Topfstedt ${ }^{2}$ \\ Caroline Gonsalves Bertho ${ }^{3}$ \\ Igor Manoel Rodrigues Costa ${ }^{4}$ \\ Raíssa Helena Ramos Tomasin ${ }^{5}$
}

\section{Resumo}

Este manifesto apresenta quatro relatos de experiências de Licenciandos no curso de Dança da Unicamp, que observaram em suas práticas docentes e nas práticas observadas em estágios, o desenvolvimento da autonomia dos alunos através da Dança. A principal das referência bibliográfica utilizada foi o livro "Pedagogia da Autonomia" de Paulo Freire, relacionando-o a outras referências teóricas sobre métodos e abordagens de Educação Somática.

Palavras-chave: Dança. Ensino. Autonomia.

\footnotetext{
${ }^{1}$ Universidade Estadual de Campinas. Professora do Programa de Pós-Graduação em Artes da Cena e dos Cursos de Bacharelado e Licenciatura em Dança. ORCID: https://orcid.org/0000-0002-94843935 Contato: pcarusot@gmail.com

2 Bacharel e Licenciada em Dança pela Universidade Estadual de Campinas. ORCID: https:// orcid.org/0000-0002-1282-4045 Contato: geduarte.top@gmail.com

3 Bacharel e Licenciada em Dança pela Universidade Estadual de Campinas. ORCID: https://orcid.org/0000-00018288-6367 Contato: carolbertho.cb@gmail.com

4 Bacharel e Licenciado em Dança pela Universidade Estadual de Campinas. ORCID: https:// orcid.org/0000-0002-1654-6476 Contato: igormrcosta@gmail.com

5 Bacharel e Licenciada em Dança pela Universidade Estadual de Campinas. ORCID: https:// orcid.org/ 0000-0003-4298-6229 Contato: raissa_tomasin@hotmail.com
} 
Conceição | Conception

Revista do Programa de Pós-Graduação em Artes da

Cena, Universidade Estadual de Campinas

Performing Arts Graduate Program Journal, University of

Campinas

\begin{abstract}
This statement describes four reports from experiences of undergraduate Dance students', who observed in their teaching practices during their internships, the development of students' autonomy through Dance. The main bibliographic reference was the book "Pedagogy of Autonomy" by Paulo Freire, relating it to other references on methods and approaches of Somatic Education.
\end{abstract}

Keywords: Dance. Education. Autonomy.

Este artigo intenta abordar o ensino de dança como forma de desenvolver a autonomia nos alunos. Apresenta-se aqui quatro reflexões de licenciados no curso de Graduação em Dança da Unicamp que, com o desejo de realizar um ensino em que prevaleça a autonomia, observaram a presença de abordagens de educação somática em suas práticas docentes e nas práticas observadas em seus estágios.

Tendo como base bibliográfica o livro "Pedagogia da Autonomia" de Paulo Freire $^{6}$, eles entendem a autonomia, no ensino de Dança, como um conjunto de ações que visam possibilitar ao aluno uma percepção de si mesmo, do seu próprio corpo, movimentos e do seu próprio processo de aprendizagem. Relacionado a isso, perceberam que abordagens e práticas de Educação Somática possibilitam a construção da autonomia em sala de aula, onde a educação pode ser um ato coletivo. A respeito desta ação coletiva nos apresenta Brandão (1981): “A educação, que deve ser um ato coletivo, solidário - um ato de amor, dá para pensar sem susto -, não pode

6Paulo Reglus Neves Freire nasceu no dia 19 de setembro de 1921, em Recife, Pernambuco. Graduado pela Faculdade de Direito de Recife (Pernambuco). Sua filosofia educacional expressou-se primeiramente em 1958 na sua tese de concurso para a universidade do Recife, e, mais tarde, como professor de História e Filosofia da Educação daquela Universidade. Em 1969, trabalhou como professor na Universidade de Harvard. Em 1980, depois de 16 anos de exílio, retornou ao Brasil para "reaprender" seu país. Lecionou na Universidade Estadual de Campinas (UNICAMP) e na Pontifícia Universidade Católica de São Paulo (PUC-SP). Em 1989, tornou-se Secretário de Educação no Município de São Paulo. Tomou frente de inúmeras campanhas de educação popular e alfabetização como o Movimento de Cultura Popular (MCP), a campanha "De Pé no Chão Também se Aprende a Ler" e a Campanha de Alfabetização de Angicos. Coordenou o Programa Nacional de Alfabetização, do Governo Goulart. Faleceu no dia 2 de maio de 1997 em São Paulo, vítima de um infarto. Fonte: http://www.paulofreire.org/paulo-freire-patrono-da-educacao-brasileira. 
Conceição | Conception

Revista do Programa de Pós-Graduação em Artes da

Cena, Universidade Estadual de Campinas

Performing Arts Graduate Program Journal, University of

Campinas

ser imposta. Porque educar é uma tarefa de troca entre pessoas, [...] De lado a lado se ensina. De lado a lado se aprende."

São apresentados aqui quatro relatos dessas experiências, sendo que dois se configuram no mesmo ambiente formal de ensino, um sob a perspectiva de observador do trabalho docente e outro pela ótica da ação docente; e os outros dois, estão inseridos em contextos não formais de ensino.

\section{Contexto da ETEC de Artes}

\section{A instituição}

A Escola Técnica Estadual de Artes de São Paulo, está localizada na cidade de São Paulo, sendo parte do complexo do Parque da Juventude, entregue a população em 2007. Este complexo compõe o próprio parque, outra escola técnica que leva o mesmo nome do parque, a Biblioteca São Paulo, e um posto do programa Acessa São Paulo. Este complexo teve como intuito revitalizar a área que antes era ocupada pela Penitenciária do Carandiru. Os prédios da ETEC de Artes e Parque da Juventude são duas construções da antiga penitenciária que não foram implodidos com o fechamento do presídio. Ambas instituições são geridas pela autarquia do Centro Paulo Souza, estando vinculada à Secretaria de Desenvolvimento Econômico, Ciência, Tecnologia e Inovação do Estado de São Paulo.

A ETEC de Artes oferece os cursos técnicos de Dança, Canto Coral, Regência, Composição e Arranjo, Eventos, Design de Interiores, Paisagismo, Artes Dramática e Processos Fotográficos. Todos os cursos são divididos em três módulos, com duração de um semestre cada. Para ingressar na escola é preciso realizar o Exame do Processo Seletivo Vestibulinho.

O curso técnico em Dança possui para seu ingresso, além do exame com questões-teste, uma prova de aptidão, que se orienta em propostas, elaboradas por alguns docentes, de exercícios de técnica de dança, criatividade e expressão corporal, avaliando se os alunos possuem os requisitos necessários para acompanhar o curso. 
Conceição | Conception

Revista do Programa de Pós-Graduação em Artes da

Cena, Universidade Estadual de Campinas

Performing Arts Graduate Program Journal, University of

Campinas

A cada semestre, 30 alunos são selecionados para ingressarem no curso. Ao final do curso o aluno recebe a o diploma de nível técnico em Dança, que assim como apresenta o site oficial da "é o profissional que desenvolve atividades ligadas à criação e à execução de dança, atuando como bailarino, dançarino, diretor ou assistente de palco e contrarregra. Domina os diferentes gêneros e estilos de dança. Emprega técnicas de dança e recursos de improvisação, em espaços cênicos, como formas de expressão corporal"7.

No primeiro módulo do curso técnico em Dança há componentes curriculares, práticos e teóricos, que organizam uma grade de conteúdos para que o aluno tenha o contato e o pensamento acerca da prática e da reflexão da Dança. São eles: Condicionamento Físico e Anatomia; Dança clássica; Danças Étnicas; Dança, Arte e Cultura urbana; Ética aplicada à Dança; História, Análise e Crítica da Dança I; Inglês Instrumental; Linguagem, Trabalho e Tecnologia; Percepção e Contato. Todas os componentes possuem carga horária de 50 horas, exceto por Dança Clássica, que possui 100 horas. Totalizando assim 500 horas de curso no primeiro módulo.

Os próximos dois textos são reflexões que se deram no mesmo ambiente de ensino - a Escola Técnica Estadual de Artes de São Paulo - sob perspectivas singulares, dado que uma experiência se dá a partir da vivência enquanto docente do curso técnico em Dança e a outra a partir da vivência como estagiário no mesmo curso.

\subsection{Ensino de dança e autonomia: uma leitura a partir da experiência em estágio na ETEC de Artes}

No fundo, o essencial nas relações entre o educador e educando, entre autoridade e liberdades, entre pais, mães, filhos e filhas é a reinvenção do ser humano no aprendizado de sua autonomia. (FREIRE, 1996)

\footnotetext{
7 Para mais informações consulte: http://www.etecdeartes.com.br/index.php/cursos/danca e http:/ / www.vestibulinhoetec.com.br/unidades-cursos/curso.asp?c=1110
} 
Conceição | Conception

Revista do Programa de Pós-Graduação em Artes da

Cena, Universidade Estadual de Campinas

Performing Arts Graduate Program Journal, University of

Campinas

Este texto tem como objetivo uma reflexão acerca de uma abordagem que se preocupa com a construção da autonomia no processo de ensino-aprendizagem. Para tanto, o recorte se emoldura, principalmente, a partir da minha vivência enquanto estagiário no curso Técnico em Dança da Escola Técnica Estadual de Artes (SP), onde estudei em meados de 2010 e para onde retornei em 2015 como estagiário.

No decorrer da minha experiência como estudante da ETEC, do ensino formal na escola pública e mesmo depois de ter decidido estudar Dança na Universidade Estadual de Campinas (Unicamp), percebi-me refletindo diversas vezes a respeito do processo de ensino-aprendizagem, sua relevância para o desenvolvimento do conhecimento e para a formação do indivíduo.

Durante os estágios de observação no curso de Dança da ETEC de Artes, tais questões começaram a ser fomentadas, pois entrei em contato com bibliografias específicas sobre o tema, bem como com questões levantadas nas disciplinas de licenciatura do Curso de Dança da Unicamp. No estágio, tive a oportunidade de entrar em contato com docentes do curso da ETEC de Artes e, a partir disso e especialmente das observações feitas nas aulas da professora Camila Bronizeski ${ }^{8}$, comecei a perceber que minha questão dizia respeito à abordagem na qual se estruturava a prática pedagógica no ensino de Dança e em como se enxerga o aluno no processo de educação, se como um indivíduo em processo contínuo ${ }^{9}$ de construção do conhecimento e de si, que possui uma bagagem pessoal, ou como uma tábula rasa, que aguarda a transferência de conhecimentos por parte do professor, este sim dotado da verdade a partir de sua posição hierárquica.

\footnotetext{
${ }^{8}$ Camila Bronizeski graduou-se em Dança pela Unicamp. É docente no curso Técnico em Dança na ETEC de Artes, tendo lecionado disciplinas de Dança Clássica, Dança Moderna e Contemporânea, Percepção e Contato, Ensino de Dança e Trabalhos de Conclusão de Curso, sendo as três primeiras aquelas onde mais atua dentro do curso.

9“ Na verdade, o inacabamento do ser ou sua inconclusão é próprio da experiência vital. Onde há vida, há inacabamento. Mas só entre mulheres e homens o inacabamento se tornou consciente" (FREIRE, 1996 p. 50).
} 
Conceição | Conception

Revista do Programa de Pós-Graduação em Artes da

Cena, Universidade Estadual de Campinas

Performing Arts Graduate Program Journal, University of

Campinas

Minha experiência e reflexão se orientam, principalmente, pela observação de uma prática docente que, de alguma forma, tinha como objetivo estabelecer uma apropriação do conhecimento corporal por parte dos alunos. Vejo ser pertinente esta reflexão para o ensino de Dança, visto que, historicamente, essa linguagem artística possuía e ainda possui, em alguns ambientes de ensino, uma abordagem que preza pela cópia e execução motora sem criticidade, através de pedagogias não tão propositoras aos indivíduos que experimentam a liberdade de (e em) seus corpos e gestos, muito menos que possibilitem uma experiência criativa. Saliento que não trato aqui das técnicas variadas de Dança já existentes, as quais se utilizam de demonstrações corporais por parte dos professores. Não encaro esse tipo de abordagem como negativa e muito menos antiquada, mas sim como ferramentas disponíveis para o ensino. O que questiono é essa prática sem construção crítica, uma atitude (no ensino e no aprender) consciente e experimentada pelo e no corpo.

\section{O porquê de uma reflexão a respeito da autonomia}

O olhar voltado para a autonomia me encanta enquanto possibilidade primeira para a emancipação do Ser, como cidadão, agente e pessoa responsável pelas ações e relações com o Outro no mundo; diferentes, pois cada qual é singular, mas iguais em humanidade, direitos e habitantes do mesmo meio.

Muitas vezes, o anseio por uma educação mais construtivista e que questione o objetivo do ensino e seus "personagens" gera discursos que se dirigem a tais perspectivas como utópicas ou, até mesmo, subversivas. Digo isso porque, tendo Paulo Freire como um dos referenciais teóricos deste texto, deparei-me, em diversas pesquisas a respeito de sua literatura, vídeos, entre outros, com críticas individuais e de movimentos educacionais, como, por exemplo, o movimento "Escola sem 
Conceição | Conception

Revista do Programa de Pós-Graduação em Artes da

Cena, Universidade Estadual de Campinas

Performing Arts Graduate Program Journal, University of

Campinas

Partido"10. Este trata as reflexões e apontamentos do educador a respeito da prática docente e do processo de ensino-aprendizagem como utópicas, comunistas, doutrinárias e partidárias, dizendo que as mesmas tiram o professor do lugar de "autoridade do conhecimento" ao colocar para o aluno a possibilidade de questionar (falar) no ambiente de ensino, de existir. Tal circunstância, ocasionada por uma onda neoliberal, bem como as falácias daqueles que acreditam em um ensino pela ordem e autoritarismo e em um aluno nulo que apenas recebe sua verdade, motivaram-me a levantar minha experiência e elaborar este texto como uma esperança utópica. Demonstrar a relevância de um processo de ensino que, em menor ou maior grau, contribui com a emancipação e a apreensão do conhecimento por parte dos indivíduos/estudantes.

Com a experiência da prática em dança e a vivência como estagiário na ETEC de Artes, observo as propostas da Educação Somática, suas ideias e técnicas, e passei a enxergá-la como um campo fértil para a construção da individualidade em detrimento da homogeneização vigente no ensino, possibilitando que a singularidade e a coletividade de diferentes se faça presente.

O recorte do estágio: a experiência da observação e o despertar do olhar para a autonomia

Apresento aqui proposições feitas na sala de aula e atitudes docentes presenciadas por mim ao longo dessa experiência. Destaco, principalmente, aquelas as quais acredito que possam possibilitar a construção de um indivíduo que se relacione com o conhecimento de forma mais autônoma e mesmo consciente, estabelecendo uma relação ativa com o mesmo.

\footnotetext{
${ }^{10}$ Escola sem Partido é um movimento político que visa estabelecer limites à liberdade do professor em sala de aula. Advindo de um onda ideológica conservadora de direita no Brasil, tem como principal alegação que, no sistema de ensino, parte do professorado se configura, atualmente, como doutrinadores marxistas. Por conta disso, o movimento luta para construir um projeto de lei que limite o abuso da liberdade de ensino, assim como disposto em um dos sites oficiais: www.programaescolasempartido.org.
} 
Conceição | Conception

Revista do Programa de Pós-Graduação em Artes da

Cena, Universidade Estadual de Campinas

Performing Arts Graduate Program Journal, University of

Campinas

\section{O Diálogo}

O diálogo entre professoras ou professores e alunos ou alunas não os torna iguais, mas marca a posição democrática entre eles ou elas. Os professores não são iguais aos alunos por $n$ razões, entre elas porque a diferença entre eles os faz ser como estão sendo (FREIRE, 1997, p. $60)$.

Talvez um dos fatores mais importantes para a construção da autonomia seja o diálogo, pois a partir dele é possível construir a relação de acordo democrático no ambiente de aprendizagem. Elucido primeiramente esse aspecto por tê-lo visto e vivenciado quando do início do estágio ${ }^{11}$ na ETEC de Artes. Ao decidir acompanhar as disciplinas de Dança Contemporânea da professora Camila Bronizeski ${ }^{12}$, ela me apresentou à turma, explicando minha condição de estagiário e perguntando aos alunos se aceitavam minha presença; estes, por sua vez, aceitaram. Essa atitude me causou certa surpresa, porque, pelo fato de eu estar dentro de uma atividade institucional e representado por uma universidade, achava normal adentrar uma sala de aula, esquecendo que aquele era um espaço pertencente aos estudantes e que, portanto, cabia a eles me aceitarem ou não. Tal atitude da docente foi pertinente, primeiramente por demonstrar ser o aluno um sujeito com o direito de se posicionar naquele espaço; e, em segundo, por abrir-me a visão para uma paisagem com alunos os quais não eram apenas "objetos inanimados" de estudo, onde o professor verificaria a execução correta dos exercícios, mas pessoalidades que estavam (e eram agentes) na construção de conhecimento.

Pode ter havido por parte dos alunos, uma aceitação por entenderem a situação como um pedido da professora, não expressando, talvez, alguma possível rejeição. Mas entendo essa aceitação como um processo, onde se constrói, aos poucos, a partir da confiança e do afeto, esse diálogo, bem como a percepção de um lugar de possibilidade de acordo. O que pude observar em outras turmas foi que

\footnotetext{
${ }^{11}$ Este período de estágio se deu no primeiro e no segundo semestres de 2015.

${ }^{12}$ Entre 2010 e 2011, fui aluno neste mesmo curso de Dança da ETEC de artes e neste período fui aluno da professora Camila Bronizeski na disciplina de Dança Clássica.
} 
Conceição | Conception

Revista do Programa de Pós-Graduação em Artes da

Cena, Universidade Estadual de Campinas

Performing Arts Graduate Program Journal, University of

Campinas

essa postura da docente, a qual se repetiu, era sincera, e possibilitava uma fissura no muro hierárquico, herança da tradição educacional da antidialogicidade ${ }^{13}$.

\section{Abordagem Somática}

As aulas que acompanhei e o curso da ETEC de Artes, obviamente, estavam amparados por um plano pedagógico, com diretrizes específicas a respeito do que se entende por conteúdos de dança (trabalhos de rolamento, queda/recuperação, modulação de tônus etc.). Entretanto, percebi uma problemática, afinal, como trabalhar tais conteúdos em um conjunto de aprendizes heterogêneos, ou seja, em estágios diferentes de conhecimento motor, estilo de dança e maturidade pessoal?

Considerei, também, dois dados: um a respeito do ambiente de ensino, apoiado em uma política tecnicista que, em geral, preza pela execução e seus aprendizados técnicos não levando tanto em conta o material humano; o outro dado diz respeito à difícil tarefa de ministrar a disciplina de Dança Contemporânea em um semestre com apenas duas aulas semanais, sabendo que a construção dessa linguagem artística possui suas técnicas, as quais são (ou deveriam ser) construídas e reconstruídas - no e pelo corpo.

Acredito, pois, que o que se dava na prática docente na ETEC e, de alguma forma, possibilitava uma mudança, era a abordagem, a qual se diferenciava da política educacional tecnicista. Essa abordagem utilizada pela professora Camila era a educação somática ${ }^{14}$. Não necessariamente uma técnica somática específica15, mas a

\footnotetext{
13Paulo Freire reflete acerca deste fenômeno como um instrumento de dominação: "não há realidade opressora que não seja necessariamente antidialógica, como não há antidialogicidade em que o polo dos opressores não se empenhe, incansavelmente, na permanente conquista dos oprimidos. (FREIRE, 1987, p. 87).

${ }^{14} \mathrm{~A}$ educação somática consiste em técnicas corporais, onde o praticante tem uma relação ativa e consciente com o seu próprio corpo no processo de investigação somática e faz um trabalho perceptivo que direciona para sua autorregulação em seus aspectos físico, psíquico e emocional (MILLER, 2011).
} 
Conceição | Conception

Revista do Programa de Pós-Graduação em Artes da

Cena, Universidade Estadual de Campinas

Performing Arts Graduate Program Journal, University of

Campinas

elaboração de práticas dentro dessa diretriz, escolhida por ela ao longo de sua formação como artista/educadora.

Vejo com a presença da abordagem somática, um suporte no ambiente da sala de aula, visto que ela possibilita uma ponte entre os conteúdos de dança e o corpo do aluno, de forma que ele possa (re)construir os dados em conhecimento sobre seu corpo, levando em consideração sua singularidade. Sendo assim, se faz possível uma leitura a respeito da intersecção da pedagogia da autonomia com a educação somática.

A prática corporal de dança contemporânea proposta pela docente e sob uma perspectiva somática, potencializava a possibilidade de uma apreensão de seu próprio corpo por parte dos estudantes. Pude observar, em sua construção de aula, os seguintes elementos: proposições de exercícios de percepção das partes do corpo, como, por exemplo, relações centro do corpo (área abdominal) e extremidades (membros inferiores e superiores); rolamentos; movimentos homólogos (partes inferior e superior), homolaterais (lados do corpo); entre outros. Tais práticas poderiam não ser, necessariamente, disparadoras de uma autonomia por parte dos estudantes, mas pude ver, na intervenção da docente, cuidados que convergiam para uma consciência do movimento. Foram eles:

A Orientação verbal e corporal - O modo como Camila conduzia o trabalho corporal, muitas vezes, estruturava-se por meio de imagens mais subjetivas e/ou de ações musculares, convidando os alunos a experimentar em seus corpos determinado exercício, orientando para que, durante sua execução, percebessem determinada ação motora. O recurso da orientação verbal se fazia perceber como uma atividade pensada, constituindo-se de orientações que contextualizavam e ampliavam o caráter imagético do movimento no corpo de cada um. De alguma

\footnotetext{
${ }^{15} \mathrm{~A}$ docente observada não dispôs de uma técnica somática apenas, tendo relatado um conjunto de conhecimentos referentes a mais de uma abordagem somática as quais utilizava dependendo da demanda da aula e de seus aprendizes.
} 
Conceição | Conception

Revista do Programa de Pós-Graduação em Artes da

Cena, Universidade Estadual de Campinas

Performing Arts Graduate Program Journal, University of

Campinas

forma, a professora também apresentava os exercícios no próprio corpo, um lugar delicado em uma aula de Dança, pois, facilmente, o professor pode se tornar um modelo corporal. Todavia, Camila incentivava os alunos, ao longo de toda a execução do movimento, a se orientarem e entenderem a proposta de movimento, não necessariamente reproduzindo o "corpo" da professora em seus próprios corpos, como um recorte e cola. A respeito disso, a artista-educadora Sílvia Geraldi problematiza:

Aulas que empreguem exaustivamente a cópia e a repetição de vocabulários e rotinas pré-determinados não serão capazes de assegurar um entendimento global da tecnologia utilizada para dançar - tecnologia compreendida aqui como a lógica que envolve a técnica (GERALDI, 2007, p. 83).

Em geral, os exercícios propostos pela docente não costumavam utilizar ações motoras que se estabelecessem em um paradigma em que prevalecesse virtuosismo técnico e demandava dos aprendizes estarem o mais conscientes de si e de seus corpos nos exercícios.

Mesmo quando se utilizava de exercícios como os battement, passo do balé clássico, um estilo com um forte valor simbólico de virtuosidade, ela se utilizava de uma alteração da linguagem que descreve o movimento, dizendo ser este um "lançamento de perna" com determinada qualidade e ritmo, trazendo a ideia da musculatura integrada e/ou do uso de imagens metafóricas, orientando os estudantes a na percepção da execução do movimento. Assim, os alunos ficavam despreocupados, em um primeiro momento, com a estética envolvida e respeitavam os seus limites quanto à possibilidade corporal.

O Espaço da Criação - Talvez uma das estratégias mais potentes que a professora utilizava era a de propor aos alunos, durante o semestre e em espaços da aula de Dança Contemporânea, que desenvolvessem pequenas células coreográficas. Estas foram sendo desenvolvidas e compartilhadas entre os companheiros de turma. 
Conceição | Conception

Revista do Programa de Pós-Graduação em Artes da

Cena, Universidade Estadual de Campinas

Performing Arts Graduate Program Journal, University of

Campinas

Dessa forma, tornava-se possível à Camila observar o quê e como aqueles elementos de Dança desenvolvidos durante o semestre corporificavam-se ou não na criação, que é, em suma, a ação da linguagem do corpo.

Visualizei, naquele elemento de proposição de criação, duas coisas as quais nunca havia refletido até então: primeiro, que a criação não é simplesmente uma prática separada da técnica de Dança, é o fazer do corpo que reorganiza de variadas formas o conhecimento dessa linguagem. Assim, técnica e criação estão intrinsecamente relacionadas entre si, como reflete Jussara Miller:

[...] questiono a ideia de que, quando o bailarino está trabalhando tecnicamente, ele possa se desligar de suas estratégias de criação e percepção, porque estaria somente treinando, e treinando, e treinando, para num segundo momento agir de modo criativo, como se buscasse, de início, um corpo técnico para dar uma resposta criativa em seguida. (MILLER, 2011, p. 152).

Segundo, que o aluno pode buscar aliar sua realidade de Dança, considerando estilos de preferência ou pelos quais tenha curiosidade, a um entendimento destes conhecimentos apreendidos durante a aula em seu "fazer" criador. Lida, dessa maneira, com um terreno fértil para que possa, primeiramente, identificar os elementos de Dança e, então, reelaborá-los. Desde o início, Camila propunha o desenvolvimento de uma composição coreográfica do interesse de cada aluno (estético, estudo, etc.) com a única condição de que fossem curtas, para que uma elaboração mais palpável fosse possível.

Nesse procedimento, havia o compartilhamento em duplas e uma abertura de cada um para toda a turma. A professora fazia, assim, apontamentos a cada um. Também havia momentos de troca entre os participantes, onde compartilhavam e apresentavam suas leituras a respeito da composição do outro; uma rede de compartilhamento e o desenvolvimento de um espaço de troca de saberes. Interessante notar, também, que toda vez que fazia seus indicativos e apresentava suas leituras diante dos solos dos estudantes, a docente se posicionava sempre em um diálogo. Assim, diversas vezes, perguntava aos alunos se as falas dela faziam 
Conceição | Conception

Revista do Programa de Pós-Graduação em Artes da

Cena, Universidade Estadual de Campinas

Performing Arts Graduate Program Journal, University of

Campinas

algum sentido para eles. Dessa forma, eles tinham a liberdade de segui-las ou não. Além disso, Camila apresentava quais as sensações e intencionalidades presentes na criação de cada aluno.

Tendo em vista a dança como uma linguagem da Arte, e esta, por sua vez, estar carregada de potencial criativo de ressignificação do mundo, o ensino da Dança se torna um espaço possível - quando assim tem por intenção o docente - , um terreno fértil ao desenvolvimento do indivíduo, do corpo que dança a si e seu entorno.

Observo, na possibilidade estabelecida pelo encontro da abordagem somática e das práticas pedagógicas com um viés mais construtivista, a disposição potencial ao desenvolvimento da autonomia no processo de ensino-aprendizagem. Dentro da minha experiência com a docente observada, suas aulas e alunos, ressalto que tais ações e recursos utilizados pela mesma não se deram como acaso, mas com a intenção de possibilitarem o desenvolvimento de artistas da Dança mais autônomos. Acredito, pois, que a partir dessa abordagem há a possibilidade de que os estudantes possam, de alguma maneira, se relacionar com os conhecimentos da Dança, relacionando o domínio técnico ao conhecimento e percepção do próprio corpo.

Se relacionar com esses pensamentos a respeito de outras perspectivas de ensino e visualizá-los de alguma forma acontecendo em ambientes que, por vezes, não seriam os ideais, diante das políticas que os regem, revelou-se importante para mim como renovação da esperança e da utopia da mudança no ensino de Arte/Dança, que é atitudinal, é escolha e é afeto.

\subsection{Danças Urbanas e a Autonomia: Construção de Saberes Conjuntos}

"Hoje desaprendo o que tinha aprendido até ontem e que amanhã eu recomeçarei a aprender"

(Cecília Meireles) 
Conceição | Conception

Revista do Programa de Pós-Graduação em Artes da

Cena, Universidade Estadual de Campinas

Performing Arts Graduate Program Journal, University of

Campinas

Este tópico tem como objetivo discutir como o ensino de dança dentro de uma instituição pública estadual pode proporcionar a autonomia do aluno no seu próprio aprendizado, usando como fundamento as Danças Urbanas. Intenta também entender como promover um ensino de Danças Urbanas mais sensível, não tão dependente da cópia de movimentos, buscando relacionar a educação somática com essa linguagem. Este texto vem como contribuição para a escassez de trabalhos acadêmicos que abordem as Danças Urbanas e seu ensino e a articulação destas com a educação somática, que trabalhe com a possibilidade de construção de um conteúdo em conjunto. A pesquisa foi feita através de pesquisa bibliográfica, além da análise de relatos vividos como professora na Etec de Artes, tanto pessoais como de alunos.

\section{Minha trajetória}

A ETEC foi minha primeira escola formal de dança, onde pude ter contato com componentes curriculares de Dança Clássica, Dança Moderna, Dança Contemporânea, Anatomia, História da Dança, Percepção e Contato, entre outras. No decorrer do curso, fui ampliando minha visão de dança e de arte, entendendo processos de criação individual e em conjunto, além de alguns pensamentos de educação somática e consciência corporal. Muito professores que lecionaram na Etec de Artes tiveram sua formação acadêmica na UNICAMP, e assim entendi meu próximo passo para continuar meus estudos: estudar Dança na universidade.

Anos depois, terminado o curso de Bacharel na UNICAMP, ingressei na Etec de Artes para lecionar o componente de Dança, Arte e Cultura Urbana (a grade curricular estava modificada). Assim que cheguei, tudo era uma grande novidade para mim. Os muitos documentos exigidos pela parte admissional e pedagógica, as regras de uso de espaço, a organização do corpo docente com equipamentos e salas de uso comum, as exigências da coordenação e finalmente, os alunos.

Fui descobrindo como tudo funcionava aos poucos, não pude contar com alguém guiando-me durante o processo. Assim, com o passar dos acontecimentos e 
Conceição | Conception

Revista do Programa de Pós-Graduação em Artes da

Cena, Universidade Estadual de Campinas

Performing Arts Graduate Program Journal, University of

Campinas

com meus próprios erros, fui entendendo como era a organização da instituição. Também procurarei ajuda da professora anterior de Danças Urbanas, Marília Mattos. Ela muito gentilmente me orientou a respeito de alguns documentos necessários para organizar as aulas, me mostrou seus planos de curso e deu algumas dicas de como abordar as vertentes. Entendi a minha própria autonomia em ir buscar as informações e como consegui-las.

O nome do componente "Dança, Arte e Cultura Urbana" carrega dois termos: Arte e Cultura. Visto isso, há uma ideia de olhar para o urbano de forma mais ampla, entendendo todo o cabedal que vem com essa denominação de Dança, seu contexto histórico e social, suas raízes e reverberações, e isso foi me dando estofo para o curso que eu buscava organizar.

Ademais, há um documento chamado "Plano de Curso", onde o curso técnico é reconhecimento pelo Governo do Estado e por outros órgãos que regulamentam o ensino técnico, com os objetivos, justificativas e os componentes curriculares do curso. Nestes componentes são discriminados a carga horária, as competências, as habilidades e as bases tecnológicas previstas para cada um. Juntando as informações estudadas com aulas anteriores, leituras de livros da área, o auxílio da professora Marília e o Plano de Curso, fui vislumbrando o que eu organizaria de conteúdo para os meus alunos.

\section{Danças Urbanas: contextualização}

As Danças Urbanas ${ }^{16}$ fazem parte de um grande contexto chamado Cultura Hip-Hop. Esta cultura, como a conhecemos hoje, vem se desenhando desde a década de 70. O cenário é a cidade de Nova Iorque, com seus imigrantes latinos, africanos e caribenhos, cada um trazendo suas músicas e danças. Somado a uma grande crise financeira e habitacional, além dos ideais de igualdade racial de Malcon X, Martin

\footnotetext{
${ }^{16}$ Há uma discussão acerca do termo que nomeia essa cultura. A autora Ana Cristina Ribeiro escreve que "Dança Urbana: seria a terminologia mais apropriada para exemplificar todas as vertentes, [...] entretanto, ainda não é amplamente utilizado." (RIBEIRO e CARDOSO, 2011, p. 21)
} 
Conceição | Conception

Revista do Programa de Pós-Graduação em Artes da

Cena, Universidade Estadual de Campinas

Performing Arts Graduate Program Journal, University of

Campinas

Luther King e o surgimento do Black Panthers, o decorrer da guerra do Vietnã e o movimento punk e hippie. A partir disso temos uma juventude que se organiza na periferia e está suscetível ao crime e com poucas condições financeiras.

Foi evidenciado o grande caldeirão cultural da cidade de New York nos Estados Unidos, e o surgimento da Cultura Hip Hop em um movimento entre culturas e raças: afro-americanas, porto riquenhas e jamaicanas, que conviviam na pobreza e marginalidade, nos primórdios dos anos 70, onde as gangues representavam a violência existente entre os indivíduos dos bairros mais desfavorecidos. (SILVA, 2014, p.21)

Alguns elementos começam a se definir dentro da Cultura Hip-Hop: o DJ (disc-jockey) é quem toca o discos de vinil, remixando-os para criar novas músicas com batidas mais acentuadas; o MC (master of ceremonies) era a pessoa que falava ao microfone durante a festa, procurando manter a exaltação do público; o Grafite, que consiste na arte visual, onde o artista utiliza os muros da cidade, do vagão do metrô, para desenhar e deixar sua assinatura; e o Breaking17, estilo de dança característico desse movimento. Esses elementos foram unidos pelo DJ Afrika Bambaataa em 1973, acrescentando mais um elemento: o conhecimento ${ }^{18}$, mas este não é um consenso seu reconhecimento como elemento.

O hip-hop emergiria de experiências de práticas dos jovens em desvantagem econômica, participantes de uma cultura distinta da ordem dominante marcada por uma série de práticas integradas incluindo a dança, a música e a arte visual com o objetivo de disponibilizar espaços para a interação e comunicação de grupos marginalizados. (MARTINS, 2005, p. 23)

\footnotetext{
${ }^{17}$ Vertente surgida no Bronx, Nova Iorque, em meados de 70. Os jovens dançavam em músicas com a batida mais acentuada, os chamados B.Boys e B.Girls (beat boys ou break boy, que dançam na batida da música). Geralmente segue uma sequência de movimentações: o Toprock, movimentações feitas na posição vertical, apresentando o estilo do dançarino; o Footwork movimentos no nível baixo utilizando as mãos e pés de apoio; e o Freeze, geralmente usado para finalizar a dança, onde o dançarino, demonstrando muita flexibilidade e força, faz uma pausa em diferentes apoios.

${ }^{18}$ Foi o pioneiro na Cultura Hip-Hop, fundando a Zulu Nation, organização responsável por unir os elementos artísticos. Definiu-se quatro elementos: DJ, MC, Graffiti e o Breaking. Esta organização preocupa-se com os conflitos da juventude da época, e foi pensando nisso que criou-se o quinto elemento: o conhecimento. Há militantes dessa Cultura que não reconhecem o quinto elemento, pois entendem como sendo algo intrínseco aos outros elementos.
} 
Conceição | Conception

Revista do Programa de Pós-Graduação em Artes da

Cena, Universidade Estadual de Campinas

Performing Arts Graduate Program Journal, University of

Campinas

No Brasil, essa cultura chega no fim dos anos 70, através da Black Music, dos poucos videoclipes disponíveis e alguns filmes que retratavam o tema. Assim, a juventude dos grandes centros urbanos se identifica com a música, as roupas, as movimentações. Porém a associação, principalmente da dança, é feita através apenas da cópia, tornando por vezes, seu entendimento confuso e divergente de outros lugares, como aponta Silva:

No Brasil, a prática da dança começou através da reprodução de passos dos filmes e vídeos clips das fitas VHS que eram duplicadas nos antigos vídeos cassetes. As movimentações eram executadas sem muito conhecimento, [...] Assim, por muitos anos os nomes originais dos passos não eram conhecidos pelos brasileiros, os quais a partir da visão e interpretação destes passos os nomearam pela associação com outros movimentos que eles reconheciam no seu ambiente. [...] Constatamos que, um mesmo movimento recebeu vários nomes de uma região para outra. (SILVA, 2014, p.19)

Quando as Danças Urbanas foram desenvolvidas no Brasil, houveram entendimentos confusos acerca de suas estruturas e fundamentações. Negraxa (2015, p.23) aponta que "tais problemas surgem no início do processo de seu estabelecimento entre nós, quando a prática, por meio meramente da cópia, distancia-se do entendimento das origens e do conceito que as produz". Assim, percebo que este "desentendimento" ainda remanesce: há um forte pensamento de que um bom dançarino é aquele que reproduz bem, sendo o ensino de passos e movimentações feito através da cópia. Poucos são os educadores que se propõem a contestar e encontrar novas práticas para o ensino.

Quando ingressei na Etec de Artes para ministrar aulas percebi que, dedicando-me a Licenciatura, não poderia deixar de lado essa formação na minha ação docente. Os pensamentos de educação somática, que pude ter contato com o trabalho de algumas professoras, o desejo de fazer uma dança consciente e que fosse absorvida pelo alunos como uma dança própria do corpo deles, mesmo quando estes 
Conceição | Conception

Revista do Programa de Pós-Graduação em Artes da

Cena, Universidade Estadual de Campinas

Performing Arts Graduate Program Journal, University of

Campinas

não tinham vivências com Danças Urbanas. Entendi que meu discurso tinha que estar refletido na minha prática.

Senti-me ligeiramente desatualizada perante tantas novas modalidades que surgiam na cena da Cultura Urbana na cidade de São Paulo e no mundo, que pensei que os próprios alunos poderiam contribuir com o conteúdo de maneira efetiva. Trazer esses novos pensamentos para aula. Assim, busquei com que eles se entendessem como sujeitos ativos do aprendizado, que buscassem seus próprios conteúdos dentro do que é proposto em aula, além de relacionar a prática nova com suas antigas, repensando-as:

\begin{abstract}
Saber que ensinar não é transferir conhecimento, mas criar as possibilidades para a sua própria produção ou a sua construção. Quando entro em uma sala de aula devo estar sendo um ser aberto a indagações, à curiosidade, às perguntas dos alunos, a suas inibições, um ser crítico e inquiridor, inquieto em face da tarefa que tenho - a ele ensinar e não a de transferir conhecimento. (FREIRE, 1996, p. 27)
\end{abstract}

As duas primeiras turmas que lecionei, em 2015, foram o primeiro módulo do período vespertino e o primeiro módulo do período noturno, com cerca de 30 alunos em cada turma. Como tive problemas na minha contratação e comecei o semestre com atraso, pude organizar poucas aulas e trabalhos. Foi um semestre atípico, mas consegui organizar as primeiras experiências com o meu planejamento.

Já em 2016, no primeiro semestre, também estava com as turmas do primeiro módulo do vespertino e do noturno, porém agora cada turma foi dividida em duas, ficando quatro turmas de 15 alunos cada. Esta organização, apesar de mais aulas, fez com que eu conseguisse ter mais tempo com cada aluno e conhecê-los melhor. Foi a primeira turma com que eu tive o semestre inteiro de fato, então pude reorganizar algumas ações e introduzir outras. No segundo semestre deste ano, repeti a organização das turmas. 
Conceição | Conception

Revista do Programa de Pós-Graduação em Artes da

Cena, Universidade Estadual de Campinas

Performing Arts Graduate Program Journal, University of

Campinas

Ao iniciar as aulas, peço para que os alunos separem um caderno para ser o diário de bordo. Esta prática, já pedida pelos professores, consistia em um caderno onde eles faziam registros informações sobre a aula: desabafos, escritos, desenhos, colagens, etc. O diário era para ser um registro livre e contínuo. Vislumbrei o diário como uma oportunidade de construção de pensamento e processo. Deixei a critério do aluno se ele quisesse escrever sobre os outros componentes, o que geralmente acontecia sem que eu os forçasse.

O primeiro registro pedido é de pesquisar algum artista brasileiro dos elementos da cultura urbanas que o aluno ainda não conhecia e que se afetou pelo trabalho. Enfatizei que registrassem tudo aquilo que os afetava, pois seria pelo afeto que os conteúdos ficariam marcados. Somado a isso, proporcionar uma prática de como se faz pesquisa, onde procurar, quais as fontes. No decorrer do semestre, pedia uma pesquisa a respeito da vertente da aula, e muitas vezes vinham novas informações. O conteúdo da aula foi-se construindo em conjunto com eles, a partir das suas visões.

O professor que desrespeita a curiosidade do educando, o seu gosto estético, a sua inquietude, a sua linguagem, mais precisamente, a sua sintaxe e a sua prosódia; o professor que ironiza o aluno, que minimiza, que manda que "ele se ponha em seu lugar" ao mais tênue sinal de sua rebeldia legítima, tanto quanto o professor que se exige do cumprimento de seu dever de ensinar, de estar respeitosamente presente à experiência formadora do educando, transgride os princípios fundamentalmente éticos de nossa existência. (FREIRE, 1996, p. 35)

Exponho algumas diretrizes recorrentes na minha organização de trabalho:

\begin{tabular}{|l|l|}
\hline Apresentação & $\begin{array}{l}\text { Apresentação da disciplina, regras para organização da disciplina } \\
\text { (trabalhos, roupas adequadas, tênis) e apresentação dos alunos (nomes, } \\
\text { outras experiências de dança, expectativas para o componente) }\end{array}$ \\
\hline História & História e origem da cultura Hip-hop nos Estados Unidos e no Brasil. \\
\hline $\begin{array}{l}\text { Documentário } \\
\text { s }\end{array}$ & $\begin{array}{l}4 \text { documentários brasileiros são abordados, sobre origem no Brasil e sobre } \\
\text { artes e intervenções visuais. ("Nos tempos da São Bento"; "Marco Zero"; }\end{array}$ \\
\hline
\end{tabular}


Conceição | Conception

Revista do Programa de Pós-Graduação em Artes da

Cena, Universidade Estadual de Campinas

Performing Arts Graduate Program Journal, University of

Campinas

\begin{tabular}{|l|l|}
\hline Vertentes & $\begin{array}{l}\text { "PIXO" e "Cidade Cinza") } \\
\text { Funky Style19; Locking20; Popping21; Breaking e o Hip-Hop Dance22 }\end{array}$ \\
\hline $\begin{array}{l}\text { Nas práticas } \\
\text { corporais }\end{array}$ & $\begin{array}{l}\text { Referências visuais: textos abordando a descrição da dança e vídeos da } \\
\text { época em que a dança surgiu, os passos básicos e seus nomes. }\end{array}$ \\
\hline $\begin{array}{l}\text { Preparação: procuro delinear a preparação buscando trabalhar as partes } \\
\text { do corpo ou as dinâmicas mais exigidas na vertente abordada na aula, } \\
\text { organizando o que há demais essencial de cada uma no corpo. Procuro } \\
\text { organizá-los em órbitas no espaço, como grandes círculos, assim, não há a } \\
\text { referência da frente da sala, e sim do conjunto, pensando na ligação com a } \\
\text { roda 23 na Dança Urbana }\end{array}$ & $\begin{array}{l}\text { Os códigos: Procuro encontrar passos de simples reprodução, ou que } \\
\text { abordem uma dinâmica característica daquela vertente. Proponho alguns } \\
\text { motes de exploração no primeiro momento (em níveis diferentes, em } \\
\text { deslocamento), e depois organizo uma pequena sequência com os } \\
\text { movimentos, ao fim anotamos os nomes no diário. }\end{array}$ \\
\hline $\begin{array}{l}\text { Organizando em conjunto: Procuro fazê-los buscar a dança urbana } \\
\text { "dentro de cada um". Peço para que os alunos se organizem em duplas, } \\
\text { trios ou grupos, e organizem esses passos apreendidos em diferentes } \\
\text { direções, níveis e organizações espaciais, com deslocamentos e mudanças } \\
\text { de nível. Percebo que até mesmo os alunos que têm mais experiência } \\
\text { naquele estilo ficam motivados com os desafios, e os que não tem, } \\
\text { conseguem executar a dança dentro do desafio }\end{array}$ \\
\hline
\end{tabular}

19 Funky Styles fazem parte das Social Dances, danças que eram feitas nos bailes e tinham a característica de passos orgânicos, de fácil entendimento para que todos dançassem juntos, ao som da Funk Music, como por exemplo James Brown.

20 Locking é uma técnica de dança criada por Don Campbell no final da década de 60. Don que ficou conhecido como "Don Campbellock", foi fundador do grupo "The Lockers" e dançavam com dinâmicas de "travar" o corpo em algumas movimentações, como pequenas pausas.

21 Técnica de Dança criada por “Boogaloo Sam" no início dos anos 70, mistura fortes contrações musculares e resistência corporal com "ondas" e sequenciamento de articulações. Tem como referência o grupo "Electric Boogaloos".

22 Dança configurada no final dos anos 80 que, com a mudança de música, começa a criar movimentos mais complexos, adaptando das outras técnicas, para se dançar ao som da música RAP.

${ }^{23}$ A roda na Cultura Hip-Hop é o momento em que o dançarino improvisa e outros dançarinos ficam em volta, formando uma roda. Acontece em eventos e festas, no momento em que o dançarino mostra suas habilidades e seus movimentos. 
Conceição | Conception

Revista do Programa de Pós-Graduação em Artes da

Cena, Universidade Estadual de Campinas

Performing Arts Graduate Program Journal, University of

Campinas

Narro agora, uma experiência de aula, onde pude relacionar os conteúdos práticos das Danças Urbanas relacionados com métodos de educação somática.

\section{Popping e a Eutonia}

O Popping é uma vertente das Danças Urbanas, surgida em meados de 1970 em Fresno na Califórnia (NEGRAXA, 2015, p. 62) sendo sua característica mais marcante as contrações musculares em forma de "explosão" no beat da música. Esta linha de movimentação exige precisão e consciência corporal. Procurei elaborar este conteúdo de forma sensível e essencial, e não apenas pela reprodução.

Organizei assim, uma dinâmica de percepção do tônus do corpo. Segundo Alexander (1991, p. 12), "tônus é definido como a atividade de um músculo em repouso aparente. Esta definição indica que o músculo está sempre em atividade, mesmo quando isso não é traduzido em movimento ou gesto." Relembrei destes conceitos de Eutonia ${ }^{24}$ e busquei adaptá-los para essa atividade.

Começando com a ação de empurrar o chão com força, com os apoios que o tocavam, para que uma contração muscular começasse a surgir no corpo, começando pelas costas e depois encontrando outros apoios a partir dessa ação de empurrar o chão. Indo para o nível médio, passava a "empurrar o ar" a sua volta, como maneira de explorar a resistência e ampliar a sensação de tonificação do corpo todo. Organizando esse pensamento de tonificação e não de tensão, os alunos passavam a andar pelo espaço, pesquisando diferentes gradações de tônus no corpo.

\footnotetext{
Nesse caso não se trata da atividade motora, no sentido mais frequente da palavra, mas sim de uma manifestação da função tônica. Essa função tônica tem a propriedade de regular a atividade permanente do músculo, que condiciona nossa postura e faz com que a musculatura esteja preparada para responder rapidamente às múltiplas solicitações da vida (ALEXANDER, 1991, p. 12).
}

\footnotetext{
24Método de educação somática criada por Gerda Alexander (alemã, nascida em Wuppertal, 1908 1994) em 1957. A palavra Eutonia (do grego: eu (harmonioso, bom) e tônus (tensão, tônus) expressa a ideia de uma tonicidade equilibrada, por meio da atenção às sensações, promove a ampliação da percepção, propiciando a flexibilidade tônica.
} 
Conceição | Conception

Revista do Programa de Pós-Graduação em Artes da

Cena, Universidade Estadual de Campinas

Performing Arts Graduate Program Journal, University of

Campinas

Dei indicações de porcentagens para que chegassem no $100 \%$ de tônus do corpo, e irem gradativamente diminuindo ou aumentando. Neste exercício não houve indicações de certo e errado, apenas como pesquisa, a fim de perceber seu limite máximo e mínimo, e encontrar o equilíbrio. "Hipertônus e hipotônus: tônus flexível que permite uma pessoa adaptar-se continuamente a situações exteriores e expressa-se adequadamente." (ALEXANDER, 1991, p.14). Após esse exercícios, os alunos se organizaram em duplas para, um por vez, tocar em partes do corpo do colega. A parte tocada deveria contrair e relaxar rapidamente, dando a ideia de "explosão" ou "choque muscular". O aluno deveria, a partir dos toques do colega, criar uma frase coreográfica com contrações musculares.

Miller também cita o tônus na sistematização de Klauss Vianna: “o tônus muscular adequado a cada situação é adquirido com base nas experiências vividas nas aulas, mediante a propriocepção: 'propriocepção é a percepção espacial do corpo em situações dinâmicas e estáticas[...]” (2007, p. 68). Miller ainda aborda os conceitos de "resistência". A partir do estudo do tônus com os alunos, pude chegar no estudo da resistência do movimento, trabalhando a "tensão dos músculos antagonistas em sinergia com os músculos agonistas [...] trata-se de um movimento de tensões opostas equilibradas" (2007, p.70) que possibilitou a exploração de uma outra técnica de movimento dentro do Popping, o Speed Control25.

Assim, através dessas explorações, pude mostrar aos alunos que é possível ter uma Dança Urbana que vem de dentro de si, possibilitando que se coloque movimentos e características próprios, a fim de aprimorar a dança. Os alunos trazem suas próprias experiências em Danças Urbanas, agregando esses conhecimentos ao conteúdo da aula. Procuro, através das investigações, fazer com que todos os alunos se sintam capazes de realizar essa dança, mesmo que distante de suas práticas. Assim, suas movimentações também contribuem para a construção de uma dança repensada, tornando-os sujeitos e compositores da dança.

25Técnica que cria a ilusão do corpo estar se movendo em câmera lenta, presente no universo da dança Popping. 
Conceição | Conception

Revista do Programa de Pós-Graduação em Artes da

Cena, Universidade Estadual de Campinas

Performing Arts Graduate Program Journal, University of

Campinas

A partir da escrita deste trabalho, pude entender e organizar muitos pensamentos que antes acometiam-me como parte intrínseca da minha ação docente. Quando pensei em realizar os exercícios pela primeira vez, confesso que os conceitos definidos de cada técnica não me passavam pelo pensamento. Inicialmente pensava em maneiras de solucionar a questão: como encontrar o essencial da movimentação das vertentes das Danças Urbanas e como eu poderia organizar o elementar dessa movimentação? Poderia simplesmente mostrar os movimentos e pedir para que repetissem, pensando em corrigir a técnica e as execuções.

Mas, acredito que não sou capaz de ministrar uma aula assim exatamente porque tive uma formação em Licenciatura. Porque tive contato com maneiras de pensar a dança de forma sensível e integral. Essas atitudes estão inerentes a minha própria dança e consequentemente com meus valores de docente. Não me sinto especialista em nenhuma abordagem somática de fato. Mas acredito que não seja demérito pensar que os conceitos que aplico em aula foram os que ficaram da minha formação, que são verdadeiramente partes do meu trabalho. É a resultante do meu afeto, reflexo de uma formação efetiva, pois ainda reverbera em minhas ações.

Por fim, nestes três semestres em que venho trabalhando como docente em uma instituição pública de formação, compreendo seus inúmeros desafios. Busco sempre que o aluno se sinta participante e ativo na construção da aula em si. Fazê-lo responsável também pelo seu aprendizado, que ele colabora com os conteúdos e com as reflexões acerca da própria prática. Busco fazer com que o aluno literalmente traga suas experiências para a sala de aula e organize os conteúdos colocados por meio do afeto (novamente o que mais o afeta, para assim, ficar o que realmente faz sentido). Os pensamentos de Paulo Freire foram imprescindíveis para mim:

Na verdade Paulo Freire não tem sequer uma teoria pedagógica definitiva. Ele tem afeto e a sua prática. [...] Paulo Freire acredita que o dado fundamental das relações de todas as coisas no mundo é o Diálogo. O diálogo é o sentimento do amor tornado em ação (BRANDÃO, 1981, p. 102). 
Conceição | Conception

Revista do Programa de Pós-Graduação em Artes da

Cena, Universidade Estadual de Campinas

Performing Arts Graduate Program Journal, University of

Campinas

Reproduzo agora um relato de aluno, que registrou no trabalho final da disciplina a experiência do componente. Pedi para que os alunos escrevessem sobre cada linguagem abordada em sala, suas características e referências. Depois que avaliassem a si próprio e ao componente.

Tenho que confessar que essas aulas me fizeram respeitar muito todo o movimento hip hop [...] mas o popping foi a técnica que mais me interessou, ví uns vídeos do grupo Eletrics (sic) Boogaloos, grupo criado por Sam "Boogaloo" Solomon, e confesso que embora esteticamente não tenha gostado cem por cento, a técnica me parece uma ferramenta magnífica, a dissociação das partes do corpo, o estudo e o controle do tônus muscular são um desafio realmente fascinante [...], além de serem ótimas inspirações a minha dança contemporânea. [...] Sabe a professora foi muito feliz nas escolhas e metodologias pois conseguiu mediar o nosso acesso as estas danças mesclando uma didática de movimento que foi muito útil e possibilitando ao mesmo que nós trocássemos experiências e sentíssemos como de fato se dá o aprendizado de danças urbanas, por meio da troca, da brincadeira, do desafio e da convivência. (Relato do aluno W.S. que no trabalho escreveu uma carta para si mesmo, grifo do aluno).

\section{A abordagem da educação somática no ensino de dança de rua como estímulo ao desenvolvimento da autonomia de jovens de um projeto social}

Esse tópico tem como objetivo mostrar um caminho de trabalho baseado no diálogo entre a técnica de dança de rua e a educação somática e o que é possível alcançar com a busca por autonomia no contexto da inclusão social. As reflexões tecidas aqui serão pautadas pela minha experiência pessoal como professora, que articula vivências como estudante de licenciatura em dança ${ }^{26}$, considerando referências bibliográficas específicas que iluminam a discussão sobre a importância do trabalho corporal no dia a dia de cada cidadão. O projeto social Grupo

\footnotetext{
${ }^{26}$ Estudante de licenciatura em dança na Unicamp (Universidade Estadual de Campinas), ingressada em 2013.
} 
Conceição | Conception

Revista do Programa de Pós-Graduação em Artes da

Cena, Universidade Estadual de Campinas

Performing Arts Graduate Program Journal, University of

Campinas

Performance de Rua será tomado como base para o desenvolvimento das proposições acima apresentadas.

\section{O projeto social}

O trabalho com inclusão social que deu origem ao Grupo Performance de Rua começou em 1991, quando a proprietária da Academia Performance27, minha mãe, Rose Maria ${ }^{28}$, educadora física e pedagoga, abriu o espaço para que cinco jovens que moravam na periferia da cidade, fizessem suas criações com dança de rua de forma gratuita. Dona Rose, como a chamavam, foi aos poucos participando mais do projeto, apoiando e atuando como educadora social.

Foi no ano de 2005 que Rose, juntamente com o coreógrafo Carlos Santana ${ }^{29}$, criaram o Grupo Performance de Rua. Na posição de diretora, começou um trabalho inteiramente seu, levando os integrantes para competições e entrando em programas culturais da prefeitura da cidade de São Carlos. Além disso, Rose também lutava para tirar os jovens da convivência das ruas, onde estavam expostos às drogas, apresentavam comportamento de rebeldia e nenhuma perspectiva de vida. Fazendo o papel de educadora social, ela marcou a vida de muitas pessoas com seus ensinamentos sobre respeito ao próximo, humildade, o valor da vida e ajudou cada um a reconhecer suas potencialidades e possibilidades. Para ela, a mudança de pensamento e a conquista de valores próprios é a principal conquista que se faz por meio da dança neste projeto.

\footnotetext{
${ }^{27}$ A Academia Performance fica localizada na cidade de São Carlos-SP. Oferece aulas de musculação, ginástica, atividades aquáticas, artes marciais e treinamento funcional.

${ }^{28}$ Rose Maria Gonsalves Bertho é formada em Educação Física pela Fundação Educacional São Carlos, Pedagogia pela Faculdade São Luiz de Jabuticabal, tem especialização em Ginástica Rítmica pela Faculdade de Educação Física de Santo André e no Método Menegati - Movimento Fluente pelo espaço Jera Organização Corporal, em Ilha Bela. Sendo proprietária da Academia Performance, atualmente trabalha como professora de ginástica e treinamento morfofuncional e é diretora no projeto social Grupo Performance de Rua.

${ }^{29}$ Carlos Henrique Mota de Santana é formado em Educação Física pela UNICEP (Centro Universitário Central Paulista) de São Carlos, fundou o Grupo Performance de Rua em 2005, onde atuou como coreógrafo por dez anos. Sua formação em dança é pelo projeto social Vida Urbana, da cidade de São Carlos com o professor Elierte Gallo e por pesquisas não formais.
} 
Conceição | Conception

Revista do Programa de Pós-Graduação em Artes da

Cena, Universidade Estadual de Campinas

Performing Arts Graduate Program Journal, University of

Campinas

Desde criança sempre estive envolvida com o Grupo Performance de Rua, convivendo com os integrantes. Em 2006, participei de uma coreografia que pretendia juntar danças de rua com movimentações do balé clássico. Gradativamente, passei a me interessar pelo estilo do trabalho e em pouco tempo me tornei uma integrante do grupo. Aos onze anos, comecei a aprender essa nova linguagem com o coreógrafo Carlos Santana, que me deu a oportunidade de ter contato com muitos dos estilos dentro da dança de rua, de desenvolver uma base técnica forte e, também, criar as minhas primeiras coreografias. Carlos abriu espaço para que eu compartilhasse minhas sequências com o grupo, ajudasse nas montagens coreográficas. Com o passar do tempo, eu já estava substituindo o coreógrafo em aula, o que marca o começo da minha história como docente.

\section{O trabalho com dança de rua no projeto Grupo Performance de Rua}

A dança de rua ${ }^{30}$ é abordada dentro do projeto Grupo Performance de Rua devido ao interesse dos integrantes por essa linguagem, desde os primeiros jovens, nos anos noventa.

As primeiras movimentações dessa dança originaram-se a partir de diversas etnias, entre americanas, latinas, africanas, constituindo o break dance ${ }^{31}$. Este, que reúne o break, o popping e o locking, faz parte da primeira fase do Hip Hop, nomenclatura trazida por Bruno Beltão (2000), sendo esta praticada até hoje (SILVA, 2011).

\footnotetext{
${ }^{30}$ Nos anos de 1960 e 1970, nas periferias de Nova York, a dança de rua surge como a voz da juventude marginalizada, sendo um dos elementos da Cultura Hip Hop, que engloba o mesmo pensamento na música, com os DJs e MCs; nas artes plásticas, com o grafite; e na dança, inicialmente com o Break Dance. Os jovens que procuram o Grupo Performance de Rua já convivem com essa manifestação, pois, até hoje, os ideais de busca pela igualdade e pela quebra do preconceito são mantidos e perpetuados não somente entre as minorias marginalizadas, mas também por diversas classes sociais e culturas, justamente por celebrar as diferenças. De acordo com Silva e Cardoso, o Hip Hop “(...) contribuiu para a criação de um ambiente fértil a manifestações de uma minoria oprimida social e culturalmente, cujo resultado foi o nascimento de um movimento político e social que se multiplica até hoje" (SILVA e CARDOSO, 2011, p.39).

${ }^{31}$ São chamadas de break dances as danças pertencente à cultura Hip Hop, sendo as principais o break (movimentações de disputa), o locking (influenciada pelo cantor James Brown) e o popping (que trabalha contrações e relaxamentos).
} 
Conceição | Conception

Revista do Programa de Pós-Graduação em Artes da

Cena, Universidade Estadual de Campinas

Performing Arts Graduate Program Journal, University of

Campinas

Na segunda fase do Hip Hop, estão os estilos que foram criados pelo mundo com outras mesclas de danças, etnias, movimentações e ideias, como o krumping, wacking, vogue, hip hop dance, vídeo dance, dancehall, house dance ${ }^{32}$, entre muitos outros que surgiram quando essa linguagem de rua chegou a outros lugares do mundo, aos palcos e à televisão.

Vindo da rua, ou seja, não sendo acadêmico, o Hip Hop não tem uma única origem, nomenclatura, metodologia ou forma específica. Cada um que trabalha com essa linguagem, manifesta-se com a sua própria leitura, incluindo suas particularidades. Não tendo certo e errado, é como se cada um criasse a sua dança de rua (BELTRÃO, 2000).

A partir das considerações tecidas acima, é possível dizer que o mesmo acontece com o ensino. O professor trabalha como melhor entende e aprende. Alguns trabalham movimentos de base das origens de alguns estilos, outros apenas sequências coreografadas pelo próprio professor que traz sua leitura particular.

É comum, também, aulas que os professores não incentivam os bailarinos a preparem o corpo adequadamente para realizar os movimentos. Por anos, acreditei que esse caminho fosse suficiente, já que sempre foi assim que essa linguagem foi aprendida, na rua. Mas hoje vejo que, estando dentro de sala de aula e em projeto social, isso não é o bastante.

O aluno aprende a técnica, mas muitas vezes não chega a trabalhar a consciência do corpo em relação às suas possibilidades de movimentos, aos seus limites, sensações e sentimentos. Desse modo, ele não aprende para além do movimento, não leva conteúdos para a vida e não cria um pensamento sobre si e sobre a busca por suas potencialidades, pela constante mudança e amadurecimento.

\section{A educação somática}

${ }^{32}$ Numa definição generalizada, podemos dizer que algumas influências destes estilos são: movimentos de luta, fotos de revista, performances de Drag Queens, danças africanas, cada um criado por grupos específicos que ganharam notoriedade e disseminaram seus estilos. 
Conceição | Conception

Revista do Programa de Pós-Graduação em Artes da

Cena, Universidade Estadual de Campinas

Performing Arts Graduate Program Journal, University of

Campinas

Meu pensamento em relação à arte da dança e ao ensino mudou com minha entrada na Unicamp (Universidade Estadual de Campinas) no curso de graduação em dança em 2013. Durante o curso, enxerguei as milhares de possibilidades de movimentos que existem, comecei a ver meu corpo com os olhos da propriocepção, entender minhas potencialidades, testar coisas novas. Minha dança, que antes era completamente técnica, feita por e para o professor, passou a ter um viés subjetivo e perceptivo, depois do estudo da educação somática.

Durante a graduação o que mais me marcou foi a primeira quebra com minhas antigas crenças, no primeiro semestre, com a professora Silvia Geraldi ${ }^{33}$, na disciplina de técnica de dança contemporânea. Ela trabalhou conosco a linha de Feldenkrais de Educação Somática.

A educação somática é um campo de estudo que engloba o conhecimento dos domínios sensorial, cognitivo, motor, afetivo e espiritual com ênfases diferentes (FORTIN, 1999), buscando aperfeiçoar as percepções de si.

No método de Feldenkrais ${ }^{34}$, o movimento é o fundamento de todo esse conhecimento, pois é o elemento de maior concretude em relação aos outros componentes (sensação, sentimento, pensamento). Feldenkrais acredita que analisando as estruturas do corpo, funções e diversos modos de operacionalidade através do movimento, somos capazes de perceber como se processa a aprendizagem e promover o refinamento gradativo da sensibilidade "e, por conseguinte, da habilidade motora e da atitude" (GERALDI,1997).

Nas aulas da professora em questão, era indicado de maneira verbal que realizássemos determinados movimentos com tempos estendidos para que cada um pudesse se perceber em seu tempo, aprendendo, assim, quais eram os nossos

\footnotetext{
${ }^{33}$ Silvia Geraldi é artista, professora e pesquisadora da dança, docente do Departamento de Artes Corporais e do Programa de Pós-graduação em Artes da Cena no Instituto de Artes da Unicamp (Campinas, SP). Possui Pós-Doutorado em Artes da Cena pelo Núcleo Interdisciplinar de Pesquisas Teatrais/LUME-Unicamp, é Doutora em Artes (2009), Mestre em Educação (1997) e Graduação em Ciência da Computação (1987), todos pela Unicamp.

${ }^{34} \mathrm{O}$ método foi criado nos anos 40 por Moshe Feldenkrais, matemático, engenheiro e físico israelense.
} 
Conceição | Conception

Revista do Programa de Pós-Graduação em Artes da

Cena, Universidade Estadual de Campinas

Performing Arts Graduate Program Journal, University of

Campinas

próprios caminhos para a realização do movimento, quais as nossas possibilidades, aguçando a auto percepção.

Muitas vezes, fazíamos essas explorações com os olhos fechados, descolandose da imagem externa de nós mesmos, da forma dos movimentos, como eu estava acostumada. Buscávamos criar uma imagem interna, com mente e corpo conectados como um só, algo novo para mim e que abriu caminho para me reconhecer e me relacionar com o movimento de outra maneira. Comecei a buscar uma autonomia do pensamento, do dançar para mim mesma, entendendo meu modo de aprender, questionando os ensinamentos e tendo mais interesse pelo como e por que a dança é feita, pensando no processo de criar e não mais apenas vendo só o que a dança produz como estética e resultado cênico.

Para minha surpresa, no final de 2014, o coreógrafo Carlos anunciou sua saída do Grupo Performance de Rua por motivos pessoais e foi, nesse momento, que assumi como coreógrafa. Logo de início, percebi a responsabilidade que estava em minhas mãos e queria ser capaz de colocar em prática o que havia conquistado até aquele ponto com os aprendizados da graduação. Agora, eu poderia compartilhar minhas aprendizagens e mostrar toda a abertura de pensamento que vivenciava. Porém, não sabia como fazer isso, pois estava ainda na metade da graduação. Havia muitas dúvidas sobre pedagogias, didáticas e mesmo minhas crenças em relação à dança.

\section{A educação somática nas aulas de dança de rua}

Na mesma época em que comecei a lecionar e coreografar no projeto, estava iniciando meus estágios na licenciatura na faculdade. Nesse sentido, o grupo e minha nova posição de coreógrafa seria um ótimo campo de estudo. Ao mesmo tempo, estagiei também na Academia Ballet \& Cia ${ }^{35}$, de Campinas, nas aulas de hip hop sênior, com alunos de 14 a 18 anos.

\footnotetext{
${ }^{35}$ A Ballet \& Cia é uma academia de dança que oferece aulas de ballet clássico, jazz, hip hop, dança contemporânea, tecido e pilates.
} 
Conceição | Conception

Revista do Programa de Pós-Graduação em Artes da

Cena, Universidade Estadual de Campinas

Performing Arts Graduate Program Journal, University of

Campinas

Tendo dois campos com a mesma linguagem de dança e faixa etária, pude comparar os dois ambientes e também testar as didáticas e métodos de ensino e criação do professor observado, Walter Lucas $^{36}$, percebendo o que para mim funcionava, o que faltava, buscando descobrir o que acredito como professora.

A escola foi importante para que eu pudesse estudar ainda mais os estilos dentro da danças de rua que já conhecia, conhecer novos meios de trabalhar, além dos movimentos de base, tais como outras dinâmicas de movimento, tempos musicais e ritmos, composições coreográficas. Na parte técnica, também pude me aprimorar, pois busquei trabalhar mais estilos dentro da dança de rua. Acredito que consegui alcançar meus alunos quando transportei essas experiências para o projeto, pois os vi interessados nestes novos focos de aula, que também são muito comuns na mídia internacional. Entre os estilos que mais estudamos estão o hip hop dance, o house dance, o vídeo dance, o dancehall, o kruping, o wacking e o vogue.

Porém, no começo, minha relação com eles era ainda de integrante do grupo. Precisava que minha mãe estivesse no ensaio para segurar o foco deles na aula, para falarem menos sobre outros assuntos e me tratarem como professora e coreógrafa, pois eu não estava sabendo me comportar como quem tem uma autoridade, assim precisava da autoridade dela.

Por um tempo passei do limite, fui autoritária nos momentos de chamar a atenção para a aula quando os alunos se envolviam em brincadeiras e falas e, no momento de corrigir movimentações. Vejo que foi preciso passar um pouco do limiar para poder encontrar o equilíbrio certo, a autoridade democrática, como é chamada por Paulo Freire (1996) em seu livro Pedagogia da autonomia, em que a construção da disciplina, jamais minimiza a liberdade, mas aposta nela, instiga a dúvida, a inquietação, da voz ao aluno, o faz pensar.

\footnotetext{
36 Walter Lucas começou seus estudos em 1999 na Academia Apollo, em São Pedro, SP. A partir de 2005 trabalhou como bailarino de eventos como "Criança Esperança", "Show da Virada" e na turnê com o cantor Daniel, pela Ballet \& Cia. Desde 2010 dá aulas, coreógrafa o grupo sênior de Hip Hop e para eventos realizados pela escola. Atualmente é coreógrafo da Banda Vision e da empresa PHK eventos.
} 
Conceição | Conception

Revista do Programa de Pós-Graduação em Artes da

Cena, Universidade Estadual de Campinas

Performing Arts Graduate Program Journal, University of

Campinas

Com tempo, e pensando criticamente sobre meu fazer pedagógico que os estágios permitiram, alcancei aos poucos a confiança no que acreditava e pretendia. Assim, comecei a trazer os conteúdos que mais me marcaram na graduação, adaptando-os à técnica da dança de rua.

Testando caminhos, fui encontrando o formato de aula que mais funcionava, em que trabalhava inicialmente um aquecimento com experimentações somáticas para que voltassem suas percepções para seus próprios corpos e para suas relações com o espaço e com os outros. Nesta parte, busquei basear-me na primeira modalidade do método Feldenkrais da Consciência pelo Movimento ${ }^{37}$, para que depois, no segundo momento, essas percepções fossem conduzidas para movimentos de base das técnicas de um estilo de danças de rua, chegando a uma sequência coreográfica dentro do estilo trabalhado.

Um exemplo de aula foi quando propus que estudássemos nossa coluna vertebral, usada de inúmeros modos em cada estilo dentro das danças de rua. Começamos observando imagens da coluna vertebral e tomando consciência das divisões das partes, as nomenclaturas, as formas e posicionamentos anatômicos.

Depois, iniciamos uma exploração de movimentos da coluna, buscando perceber cada vértebra e as diferenças de possibilidades articulares de cada parte. Num primeiro momento, de maneira livre, sem forma e caminho específicos, para depois perceber como a coluna trabalha em movimentos do estilo Dancehall ${ }^{38}$. Para finalizar, conduzi o trabalho para uma sequência coreográfica dentro desta linguagem e uma roda de conversa para que eles pudessem pensar e falar sobre suas percepções na aula.

Algumas frases que os alunos compartilharam foram: como é mais difícil mexer uma parte da coluna do que a outra e de como é difícil ficar com os olhos

\footnotetext{
37“"Nas aulas de Consciência pelo Movimento, o profissional conduz lições para grupos de pessoas por meio de instruções verbais. A condução deve fornecer tempo suficiente para que os alunos executem os movimentos num ritmo individual e sejam capazes de explorar, com conforto e segurança, novas soluções com as antigas rotinas mediante a auto investigação" (FELDENKRAIS, 1977, p. 104) 38Dancehall é um estilo dentro da dança de rua dançado com um estilo de música também chamado dancehall. Ele é composto pela junção do hip hop com movimentações de danças africanas.
} 
Conceição | Conception

Revista do Programa de Pós-Graduação em Artes da

Cena, Universidade Estadual de Campinas

Performing Arts Graduate Program Journal, University of

Campinas

fechados. De modo que o que propus, ajudou-os a sentir e entender sua coluna; ou ainda que, na sequência coreográfica, os caminhos de movimento ficaram mais claros depois de se perceberem na primeira parte da aula.

Foi gratificante vê-los pensando sobre si mesmos, aguçarem suas propriocepções, descobrirem novos movimentos e entenderem seus corpos. Isso me trouxe uma sensação de quando me percebi capaz de fazer isso nas aulas da graduação e me incentivou na continuidade da busca de outros caminhos.

Tentei aos poucos incluí-los no meu processo criativo, para que tivessem voz, para criarem também e os pedia sugestões e ideias. Assim, iniciamos a montagem de um espetáculo, tendo como mote o uso desenfreado do telefone celular e as mudanças das relações pessoais com as novas redes de comunicação. Assistimos filmes sobre o assunto, pedi que escrevessem sobre suas relações com essas tecnologias, incentivei-os a pensar sobre esse tema, para que fossem críticos e para que pudéssemos levar o nosso público a pensar também sobre isso.

Depois da estreia do espetáculo \#LOG OFF39, fizemos uma roda de conversa para analisarmos juntos os erros, acertos e reverberações. O que mais me marcou na fala deles, naquele dia, foi quando compartilharam sobre a "vibe" que sentiram ao dançar.

“Vibe" vem do inglês e significa vibração. É um termo do vocabulário popular norte americano, atualmente muito usada em músicas de hip hop para falar de uma atmosfera emocional sensitiva que se estabelece no contato com o outro ou com uma música. Eles falaram que realmente sentiram as sensações que procuramos passar com o tema em questão e que seus amigos e familiares que assistiram, também relataram terem entendido nossa mensagem e se emocionado com a energia que criamos no local de apresentação.

39 O espetáculo \#LOG OFF estreou no dia dois de setembro de 2016, na Oficina Cultural Sérgio Buarque de Holanda, de São Carlos. 
Conceição | Conception

Revista do Programa de Pós-Graduação em Artes da

Cena, Universidade Estadual de Campinas

Performing Arts Graduate Program Journal, University of

Campinas

Para mim, essas relações estabelecidas entre os bailarinos, com o público e o espaço, que foram relatadas por eles, é o que Renato Ferrarini ${ }^{40}$ descreve como presença. Para Ferracini, trata-se de "uma certa escuta do fora que inclui o outro, o espaço e o tempo na tentativa de estabelecer uma relação coletiva de jogo potente e poético" (FERRACINI, 2014).

O corpo se coloca vulnerável a atravessamentos de forças para que todas as relações juntas possam compor a performance. Para alcançar essa abertura, acredito que o corpo do bailarino tem de estar íntegro, mente e corpo em comunhão, assim como buscamos trabalhar nas aulas.

Vi todos se transformando, transformando suas performances, suas relações uns com os outros, seus comportamentos dentro de sala e no palco. Aos poucos, fui conseguindo criar uma nova relação com eles, guiada pelo respeito mútuo.

Assim como ouvia a suas perguntas, críticas, eles escutavam e acreditavam no que buscava com eles. E, de acordo com Freire, "Resultando da harmonia ou do equilíbrio entre autoridade e liberdade, a disciplina implica necessariamente o respeito de uma pela outra, expresso na assunção que ambas fazem de limites que não podem ser transgredidos" (FREIRE, 1996, p. 54).

\section{A autonomia como inclusão social na adolescência}

Mesmo sendo um projeto social aberto a todas as idades, a maioria daqueles que participam do Grupo Performance de Rua têm entre doze e vinte anos. Nesta faixa etária, as mudanças, os processos de amadurecimento, as relações são muito importantes para definir os adultos que serão.

Para Winnicott, pediatra e psicanalista inglês, a adolescência é a transição da dependência absoluta dos pais para a independência relativa em que o indivíduo tem a necessidade de ser e a tendência inata à integração (OLIVEIRA, 2010). Nesta

40 Renato Ferracini é graduado em Artes Cênicas (1993), mestrado (1998) e doutorado (2004) em Multimeios, todos pela UNICAMP. É ator-pesquisador e atualmente Coordenador do LUME - Núcleo interdisciplinar de Pesquisas Teatrais da UNICAMP. 
Conceição | Conception

Revista do Programa de Pós-Graduação em Artes da

Cena, Universidade Estadual de Campinas

Performing Arts Graduate Program Journal, University of

Campinas

fase, o lúdico da criança é negado para dar lugar ao real, os adolescentes buscam se entender de maneira concreta e para isso têm a necessidade de se integrarem a grupos de interesses comuns, com ideias e modos de viver parecidos. Estando isolado dos pais, podem se perceber e tentar se entender. Acredito que o projeto se torna esse local de convivência para auto aprendizagem, em que se identificam e têm suporte para buscar sua maturidade, suas escolhas próprias, assim, sua autonomia.

O objetivo do projeto de incluir socialmente é, assim, favorecido pelo esforço de propiciar experiências que estimulem a autonomia nas aulas de dança. Vejo que há um aumento da auto aceitação entre os alunos e uma aceitação dos colegas como eles são, ampliando o respeito pelas escolhas de cada um, fator importante para o convívio em sociedade. Através da experiência de criar com o corpo, eles têm a possibilidade de alcançar autonomia para fazer escolhas na vida e a humildade para tentar entender outras visões e modos de pensar, abrindo-se à novas possibilidades e percebendo que podem se transformar.

Abertos às sensações e sentidos, estão mais abertos a escutar os ensinamentos da Diretora sobre pensar antes de agir, pensar também no outro, acreditar no bem que todos podem fazer, ou seja, no agir criticamente sobre a vida, em estar num contínuo processo de aprendizagem.

Por fim, concluo dizendo que como professora, cada vez acredito mais na importância do trabalho corporal para formação do indivíduo e, assim, desejo continuar neste caminho de ensino que começa a dar frutos e que, certamente, estará sempre se aperfeiçoando com a constante potência transformadora da arte e da educação.

\section{A construção da autonomia do aluno através da Técnica Klauss Vianna: $O$ encontro entre educação somática e criatividade}


Conceição | Conception

Revista do Programa de Pós-Graduação em Artes da

Cena, Universidade Estadual de Campinas

Performing Arts Graduate Program Journal, University of

Campinas

O texto que você está prestes a ler nasceu da minha descoberta e trajetória de estudo da técnica Klauss Vianna dentro e fora da universidade nos últimos seis anos. Meu primeiro contato foi com a prof. ${ }^{a}$ Dr $^{\mathrm{a}}$ Jussara Miller $^{41}$ que atuou no primeiro semestre de 2011 como professora convidada nas aulas de Técnica do curso de Dança da UNICAMP. Um semestre de estudo e eu já tinha consciência de que precisava de mais. Precisava estudar mais, dançar mais, mergulhar nesta técnica.

As vivências, ideias e reflexões que aqui trago, estão embasadas em meus estudos como observadora, estagiária, professora e intérprete na técnica Klauss Vianna e partem de experiências como professora em três espaços distintos, com alunos entre 3 e 13 anos.

\section{Um pouco sobre a história de Klauss Vianna e de sua técnica}

Klauss Vianna nasceu na capital mineira em Belo Horizonte e, desde muito cedo, já se interessava pelo corpo e seus movimentos. Iniciou seus estudos em balé clássico com Carlos Leite e posteriormente, com Maria Olenewa. Com o tempo, surgiram reflexões e inquietações sobre a forma como o balé era ensinado no Brasil. Como ele mesmo escreveu:

Sempre discordei da forma pela qual a técnica clássica chega aos bailarinos, no Brasil. Não discuto a beleza e a eficiência do clássico ao contrário, amo o clássico -, mas há alguma coisa que se perdeu na relação entre professor e aluno e que faz da sala de aula um espaço pouco saudável. (VIANNA, 2008, p.30)

A crítica de Klauss não se limita à relação afetiva entre professor e aluno mas considera, principalmente, o desenvolvimento e a construção da técnica no corpo do bailarino. Ele afirmava que “O problema é que professores e bailarinos repetem apenas a forma e isso não leva a nada. O processo deveria ser o oposto: a forma surgir como consequência do trabalho." (VIANNA, 2008 p.30)

\footnotetext{
41Jussara Miller é bailarina, coreógrafa e professora no Salão do Movimento e na Pós Graduação em Técnica Klauss Vianna, na PUC-SP. Graduada em Dança pela UNICAMP, onde desenvolveu também sua pesquisa de mestrado e doutorado. É autora de dois livros: "A Escuta do Corpo" e "Qual o corpo que dança?", ambos publicados pela editora Summus.
} 
Conceição | Conception

Revista do Programa de Pós-Graduação em Artes da

Cena, Universidade Estadual de Campinas

Performing Arts Graduate Program Journal, University of

Campinas

Foi, aos poucos, utilizando como base as posições e movimentos da técnica clássica, juntamente com a observação dos corpos em movimentos cotidianos e as sensações e articulações do seu próprio corpo, que passou a encontrar seus próprios caminhos de movimento. Em 1959, criou o Balé Klauss Vianna, juntamente com Angel, grande amiga que viria a se tornar sua esposa. Klauss foi de Minas para a Bahia, onde, em Salvador, por convite de Rolf Gelewsky ${ }^{42}$ e Lia Robatto ${ }^{43}$, atuou como professor na Universidade Federal da Bahia (UFBA), depois para o Rio de Janeiro-RJ, onde trabalhou como professor na Escola Municipal de Bailados, como coreógrafo e ator em peças de teatro.

Como professor, cada vez mais foi experimentando suas teorias e impulsos, trabalhando com as mais diversas pessoas e construindo um encontro entre educação somática - que nasceu da observação e percepção de cada corpo - e criatividade. Em 1980, mudou-se para São Paulo, dirigiu a Escola de Bailados do Teatro Municipal e depois o Balé da Cidade de São Paulo. Em 1992, fundou a Escola Klauss Vianna de formação de bailarinos.

Jussara Miller teve os primeiros contatos com a dança de Klauss Vianna quando ingressou no curso de Dança da UNICAMP, em 1985. Um ano depois participou de um curso de férias com o próprio Klauss. A partir daí, foi buscando os estudos propostos pelo mestre e começou a fazer aulas com Rainer Vianna, filho de Klauss. Participou da formação profissional na técnica e em 1992, foi convidada por Rainer Vianna a dar aulas na Escola Klauss Vianna. Ao longo desses anos Jussara Miller vem atuando como pesquisadora, intérprete e professora de técnica Klauss Vianna. Desenvolveu sua pesquisa de mestrado e doutorado na técnica e publicou dois livros sobre sua pesquisa.

\footnotetext{
42 Bailarino e coreógrafo nascido na Alemanha em 1930. Aos 30 anos veio para o Brasil para dirigir a escola de Dança da UFBA, onde trabalhou por quinze anos.

${ }^{43}$ Nasceu em 1940 em São Paulo. Em 1956 foi para Salvador trabalhar como assistente de Yanka Rudzka. Se formou em Dança pela UFBA, onde lecionou por um tempo. Foi bailarina e reconhecida principalmente como coreógrafa, recebeu em 2007 a Ordem do Mérito Cultural.
} 
Conceição | Conception

Revista do Programa de Pós-Graduação em Artes da

Cena, Universidade Estadual de Campinas

Performing Arts Graduate Program Journal, University of

Campinas

\section{Os Três Espaços: Salão do Movimento, Ninin e Teatro Livre Abigail Wimer}

Durante um ano acompanhei a turma de alunas do Salão do Movimento ${ }^{44}$ com idades entre cinco e nove anos, elas compunham um grupo heterogêneo em idade mas muito aprofundado na criatividade e percepção corporal. Muitas alunas já faziam aulas com a Jussara Miller desde cinco anos de idade e com toda essa bagagem, ajudavam a consolidar a velocidade admirável de fluxo de movimento criativo ao se relacionarem com as propostas das aulas. Outra particularidade desse grupo é que muitas meninas eram filhas de atores que compõem um polo criativo em Barão Geraldo, distrito de Campinas-SP.

Fui convidada em 2014 a trabalhar em um espaço chamado Ninin - Educação e Liberdade, localizado próximo ao bairro do Castelo, em Campinas-SP. A proposta desse espaço é de receber crianças para passar parte do dia oposta ao período escolar ou para oficinas específicas, com horários flexíveis, no intuito de suprir a demanda de um espaço de educação não formal para crianças, cujos pais trabalhem em ambos os períodos e/ou que queiram proporcionar uma experiência complementar aos estudos formais.

A proposta da $\operatorname{Ninin}^{45}$ não é de substituir o ensino formal mas, sim de complementar. Com inspirações nas pedagogias Montessori, Waldorf e Freiriana ${ }^{46}$, a Ninin oferece oficinas de dança, música, circo, reciclagem, horta, entre outras, para crianças com idades entre um e seis anos. Uma característica do espaço é que as crianças entram e saem das atividades de acordo com sua vontade, assim, se elas preferirem fazer outra atividade, são livres. Certos acordos eram estabelecidos entre o educador e a turma sobre as regras para que essa liberdade não atrapalhe o andamento da oficina. Foi desafiador e muito interessante lidar com essa proposta.

\footnotetext{
${ }^{44} \mathrm{O}$ Salão do Movimento é um espaço de dança e educação somática gerido por Jussara Miller e localizado na cidade de Campinas - SP, na rua Abílio Vilela Junqueira, 712 Guará - Barão Geraldo.Mais informações no site: http:/ / salaodomovimento.art.br/

45Mais informações no site: http://www.ninineducacao.com.br/

${ }^{46}$ Essas pedagogias diferem das mais tradicionais e valorizam a compreensão e não a memorização, o professor como mediador e a família como participante ativa no processo de aprendizagem. O aluno é considerado o centro do processo pedagógico.
} 
Conceição | Conception

Revista do Programa de Pós-Graduação em Artes da

Cena, Universidade Estadual de Campinas

Performing Arts Graduate Program Journal, University of

Campinas

O Teatro Livre Abigail Wimer47é um método de ensino de teatro para jovens e crianças, desenvolvido por Abigail Wimer na cidade de São Paulo-SP. O curso para crianças recebe alunos com idade entre 6 e 13 anos e prevê aulas de música (com foco em canto), artes plásticas e dança (com foco em expressão corporal), além do teatro. Aos sábados entre $9 \mathrm{~h} 30$ e 13h, com intervalo para lanchar, os alunos passam por todas essas propostas que variam em ordem e duração. Pelo fato de os alunos não buscarem esse curso com o enfoque nas aulas de dança e sim no teatro, o grupo acaba sendo extremamente heterogêneo, tanto em desenvolvimento criativo quanto em percepção corporal, até porque muitos já estão numa fase de crescimento e mudanças rápidas, característicos da pré-adolescência.

\section{O Processo Lúdico}

O recorte aqui apresentado tem como embasamento a primeira etapa da técnica Klauss Vianna ${ }^{48}$, o processo lúdico. Denominado “o acordar”, o processo lúdico auxilia o aluno a se conectar com o próprio corpo, iniciando uma jornada de autoconhecimento e expansão criativa. De acordo com Jussara Miller, "no processo lúdico, o corpo é despertado, desbloqueado, causando a transformação dos padrões de movimento".

No trabalho com crianças e pré-adolescentes, o processo lúdico é ideal pois possibilita a expansão, uma nova forma de expressão e ao mesmo tempo, auxilia no desenvolvimento motor, intelectual, criativo, na socialização e na percepção do próprio corpo. Jussara Miller, ao longo de seu trabalho com a técnica Klauss Vianna, desenvolveu adequações para trabalhar com crianças: “A proposta é trabalhar os princípios da dança, preservando a espontaneidade de movimento da criança, não

\footnotetext{
${ }^{47} \mathrm{O}$ Teatro Livre Abigail Wimer é uma formação em teatro e artes integradas, com metodologia própria, criada em 1994 e que visa um desenvolvimento consciente através das artes, valorizando o trabalho em grupo. Mais informações no site: https://teatrolivre.wordpress.com/

${ }^{48}$ De acordo com estruturação do curso de formação da Escola Klauss Vianna que ao longo de três anos trabalhava os seguintes tópicos: Processo Lúdico, Processo dos Vetores e Processo Criativo e/ou Processo Didático.
} 
Conceição | Conception

Revista do Programa de Pós-Graduação em Artes da

Cena, Universidade Estadual de Campinas

Performing Arts Graduate Program Journal, University of

Campinas

oferecendo sequências coreográficas prontas, mas estimulando-a a incorporar a dinâmica de investigação do movimento no ato de dançar." (MILLER, 2012 p.84)

Meu primeiro contato com a técnica Klauss Vianna aplicada para crianças foi no Salão do Movimento, com uma turma de meninas que tinham entre 5 e 9 anos. A primeira parte da aula era ministrada pela Jussara Miller, onde eu observava e eventualmente auxiliava, seguida por um lanche que consistia em uma toalha estendida em meio ao jardim com as crianças todas ao redor. Depois vinha a parte em que eu trazia minhas próprias propostas. Com as crianças já aquecidas, meu desafio era trabalhar propostas interessantes o suficiente para que elas, mesmo depois de uma hora de aula e um piquenique, ainda se envolvam.

Durante esses cerca de 40 minutos, nessa segunda parte da aula, nós misturávamos processo lúdico com brincadeiras e muita improvisação, que eu buscava relacionar com os temas trabalhados pela Jussara na semana anterior. Esse grupo foi especialmente desafiador. Eram crianças que já estavam a algum tempo tendo aulas de dança e outras linguagens artísticas, e muitas delas eram filhas de artistas, principalmente atores.

O próprio Klauss Vianna, durante os anos em que trabalhou na Escola Municipal de Bailados do Rio de Janeiro, foi responsável pela turma infantil e sempre trabalhou o lúdico com as crianças: "Falava do corpo, das funções dos ossos, brincávamos de roda, pedia para que elas dançassem o que gostavam de dançar nas festas, lia histórias. [...] Bastava dar um estímulo e pronto, elas reagiam, brincavam, riam." (VIANNA, 2008, p.46).

O primeiro tópico trabalhado no processo lúdico é a Presença. A presença se refere ao estar inteiro no presente, consciente em três níveis, o eu, o espaço e o outro. Pode parecer fácil e até banal mas ao trabalharmos a presença, percebemos o quão volátil ela pode ser. Ainda mais com a quantidade de informação na atualidade, que nos desconecta do nosso próprio corpo e nos conecta com uma série de dados que, muitas vezes, não são nem físicos ou palpáveis, na verdade fazem parte de uma rede virtual. 
Conceição | Conception

Revista do Programa de Pós-Graduação em Artes da

Cena, Universidade Estadual de Campinas

Performing Arts Graduate Program Journal, University of

Campinas

Minha experiência mais recente como professora foi no Teatro Livre Abigail Wimer e lá os alunos são, em sua maioria, mais velhos do que as alunas do Salão do movimento. Um desafio muito grande ao trabalhar com eles foi o julgamento que muitos faziam sobre seus próprios movimentos durante o processo. Percebi, ao longo do tempo, que para eles desligarem um pouco desse pré-conceito sobre sua própria expressão, tinha que inserir alguns elementos que os mantivessem de certo modo distraídos. Uma das propostas que eles mais gostavam, e que veio da minha experiência no Salão do Movimento, consistia em jogarem uma bolinha uns para os outros sem deixar cair, tudo enquanto dançavam e também com uma proposta musical. Assim, trabalhavam a presença nos seus três níveis, tinham que estabelecer contato através do olhar com o colega para quem passavam a bolinha, ter consciência do seu próprio corpo, do espaço e do outro. E com tantos desafios acabavam por se preocupar menos com seus próprios julgamentos.

O segundo tópico abordado é Articulações. Nesse tópico, as propostas levam o foco para cada uma das principais articulações do nosso corpo e a experimentação nos mostra que o movimento surge a partir dos espaços articulares. Como o próprio Klauss coloca: “Os espaços correspondem às diversas articulações do corpo, no qual é possível localizar fluxos energéticos importantes e no qual se inserem os vários grupos musculares". As crianças exploram o movimento parcial, que isola cada uma das articulações e, o movimento total vai se tornando mais completo a cada estudo detalhado de cada articulação.

Um dado importante é que, sempre, apresento os nomes dos ossos, mesmo para as crianças mais novas. Não é cobrado que elas decorem, mas assim elas vão se familiarizando e se conectando com maior naturalidade a sua própria anatomia. Durante uma aula Teatro Livre Abigail Wimer, tive inclusive a devolutiva de um aluno que estava estudando sistema esquelético e me disse que, foi bem na prova de ciências porque se lembrou dos nomes, localização e função dos ossos. 
Conceição | Conception

Revista do Programa de Pós-Graduação em Artes da

Cena, Universidade Estadual de Campinas

Performing Arts Graduate Program Journal, University of

Campinas

Cada tópico do processo lúdico se relaciona com os anteriores e posteriores. $\mathrm{O}$ estudo de articulações não deixa de influenciar o estado de presença, muito pelo contrário, o aprofunda e assim também se relacionam todos os outros temas.

O terceiro tema trabalhado é Peso. Para estudar peso utilizamos diversas gradações de tônus muscular que nos levam a sensação de abandono, passando pela leveza e fluidez e que, em outro extremo, leva à imobilidade. Esse controle para as crianças mais novas, como tive na Ninin, é mais difícil por conta do corpo da criança ser muito leve e saltitante. Por outro lado, com os mais velhos, como no Teatro Livre, a percepção dos membros e extremidades, que nessa idade crescem rapidamente, a dificuldade é equilibrar o tônus pelo corpo todo, expandindo e conectando numa movimentação mais fluida.

O próximo tema, Apoios, nasce do trabalho com peso e corresponde a relação entre o peso e a superfície em que o corpo se apoia, que na maior parte das vezes é o chão. Nessa etapa, diferenciamos o apoio ativo do apoio passivo, que se diferenciam de acordo com o uso ou não uso da pressão de uma parte do corpo no chão ou superfície de apoio. O estudo dos apoios abre as possibilidades de movimentação na medida em que percebemos que não necessariamente temos que apoiar os pés para nos deslocarmos; podemos apoiar a cabeça, as escápulas, o quadril, qualquer parte do corpo pode se tornar um apoio ativo.

Alguns temas são mais difíceis de serem trabalhados com crianças mais novas e são necessárias adaptações, propostas diferentes para cada faixa etária. No Salão do Movimento, as crianças entravam a partir dos cinco anos de idade. Quando fui convidada a trabalhar na Ninin, a turma era de crianças entre três e seis anos. As crianças mais novas, apesar de muito criativas, conectam-se mais pela imitação do que as mais velhas. Enquanto nas aulas do Teatro Livre, eu sempre dançava junto para incentivar, nas aulas da Ninin eu dançava junto para auxiliar como exemplo, não a ser imitado mas para facilitar a compreensão da proposta. Percebi que enquanto as crianças mais velhas estabeleciam apoios no espaço, as mais novas, com 3 ou 4 anos, gostavam de apoiar em mim também. Elas transitavam entre apoiar em 
Conceição | Conception

Revista do Programa de Pós-Graduação em Artes da

Cena, Universidade Estadual de Campinas

Performing Arts Graduate Program Journal, University of

Campinas

superfícies do espaço e a superfície do meu corpo. Estudavam seus corpos ao encostar no meu. Busquei respeitar essa necessidade e aproveitá-la para compor movimentos que relacionavam nossos corpos e apoios e assim a proposta se desenrolava.

O próximo tema do processo lúdico é Resistência. Esse, para mim, de longe é o mais desafiador dos temas quando trabalhado com as crianças. O trabalho com resistência pode surgir a partir da pressão exercida sobre um apoio, que gera certa resistência. Ao extrapolarmos essa pressão para além de uma superfície como a parede ou o chão e passamos pressionar o ar, tecidos ou o corpo do outro, vamos gerando tensões entre musculaturas, que resultam em diferentes níveis de resistência. Um importante estudo desenvolvido neste tema é a pausa. Como escreve Miller (2007, p. 70): “Na pausa não há apenas interrupção do movimento; pelo contrário, na pausa há um movimento interno, com uma atenção e prontidão musculares em que o corpo ganha outra dimensão, ou melhor, uma tridimensão, o que poderíamos chamar de presença cênica".

Lembro-me das propostas de estudo da pausa com a turma do Salão do Movimento. As meninas já tinham grande familiaridade com a técnica e as proposta e suas pausas eram precisas, imbuídas de uma presença e prontidão potentes. Quando voltavam ao movimento, além da precisão, elas tinham impulso, projetavam seus corpos em saltos, movimentos totais e expressivos, fortes ou leves, mas geralmente com uma velocidade mais rápida.

O penúltimo tema a ser trabalhado é Oposições. As propostas dessa etapa são das mais divertidas para as crianças. Elas se desafiam em expansões e recolhimentos cada vez mais inovadores e eu incentivo ao propor partes do corpo a serem opostas e níveis a serem utilizados. No jogo de oposições, os alunos vão compreendendo melhor os espaços articulares e utilizando como base todas as experimentações até esse ponto, passando a compreender o corpo com maior tridimensionalidade, esculpindo a movimentação e buscando diferentes estados corporais. 
Conceição | Conception

Revista do Programa de Pós-Graduação em Artes da

Cena, Universidade Estadual de Campinas

Performing Arts Graduate Program Journal, University of

Campinas

Mais uma vez aqui chamo a atenção para os alunos mais velhos, na faixa dos 12 ou 13 anos, em relação à dificuldade em se conectarem com suas extremidades, principalmente sem perder a ideia de alinhamento entre as partes que estão sendo opostas, mesmo porque a oposição não é só trabalhada na pausa mas também na fluidez e, para os mais velhos, essa consciência é mais complexa. Nas aula com o tema oposição, ministradas no Salão do Movimento, a Jussara utilizava elásticos para desenhar as oposições nos corpos das alunas em pausa. Elas eram muito criativas e a cada pausa traziam oposições muito além do óbvio, desafiavam a gravidade em apoios precários e utilizavam as alavancas da própria oposição para a sustentação. Não poucas vezes me surpreenderam com a precisão e naturalidade que incorporavam em cada proposta.

O último tema desenvolvido no processo lúdico é o Eixo global. Aparentemente o tema mais simples, o eixo global é o último a ser estudado justamente pelo fato de ser utilizado em grande parte do cotidiano. Só depois de termos contato com todos os outros temas, o contato com o chão ser mais íntimo e a compreensão das macro e micro movimentações estar mais desperta é que podemos revisitar o alinhamento e transcender os vícios posturais cotidianos. Ao estudar o eixo global, os alunos se percebem mais empoderados, mais donos de si e conhecedores do próprio corpo.

O estudo do processo lúdico, que culmina no eixo global, é a porta de acesso para o estudo dos vetores que é mais adequado para o ensino de jovens e adultos. No entanto, a retomada de um novo ciclo dos temas do processo lúdico leva a uma nova compreensão, um aprofundamento e ao mesmo tempo expansão de possibilidades de movimento.

As alunas do Salão do Movimento são um exemplo disso. Os caminhos de movimento vão se tornando cada vez mais complexos e orgânicos.

Técnica Klauss Vianna e Autonomia 
Conceição | Conception

Revista do Programa de Pós-Graduação em Artes da

Cena, Universidade Estadual de Campinas

Performing Arts Graduate Program Journal, University of

Campinas

Passando por diferentes experiências como proponente da técnica Klauss Vianna, percebo as transformações que levam os alunos a compreenderem melhor seus corpos, ritmos e sentimentos e por conta disso, acolherem as particularidades grupais e individuais. Ao pensarmos sobre a autonomia na técnica, é importante ressaltar a seguinte questão que Paulo Freire (1996, p.26) nos traz: “Não temo dizer que inexiste validade no ensino de que não resulta um aprendizado em que o aprendiz não se tornou capaz de recriar ou de refazer o ensinado, em que o ensinado que não foi aprendido não pode ser realmente aprendido pelo aprendiz."

Partindo da ideia de que o professor não é o detentor do conhecimento, sobre a questão do aprendizado e de como ele deve ser fomentado, técnicas de dança que tenham como ferramenta a exploração criativa das movimentações, são um caminho plausível de se trabalhar autonomia em sala de aula.

Logo no início do livro A Dança, Klauss Vianna escreve o seguinte texto, que dialoga diretamente com a ideia de autonomia:

Em vez de conduzir adaptações para maneiras de dançar ou se movimentar que me agradam ou com as quais me identifico, prefiro apresentar informações e estimular as contribuições individuais. É o que pretendo com base nas reflexões - e dúvidas - contidas neste livro. Que, espero, não busque nem estabeleça certezas, mas desperte o desejo permanente de investigação perante a dança e a arte - que, para mim, se confundem com a vida." (VIANNA, 2008, p.15)

Mais do que uma técnica, a pedagogia elaborada por Klauss proporciona até hoje a construção de um conhecimento motor, sinestésico, afetivo e sensível que é próprio do aluno, que tem a possibilidade de acessar cada conteúdo diversas vezes, recodificando e ramificando seus estudos a cada vez, tornando -se protagonista de sua própria busca por novas descobertas.

Ao longo dessa trajetória, cada proposta de aula aborda os conteúdos no intuito do desenvolvimento criativo. A união entre educação somática e criatividade na técnica Klauss Vianna é construtora de autonomia. Um grande parceiro no desenvolvimento da criatividade, principalmente nas crianças, é a curiosidade. A 
Conceição | Conception

Revista do Programa de Pós-Graduação em Artes da

Cena, Universidade Estadual de Campinas

Performing Arts Graduate Program Journal, University of

Campinas

curiosidade serve como gatilho de acesso para um novo conteúdo, uma nova exploração e devidamente abordada ela funciona como ferramenta de conhecimento. Como o próprio Freire nos coloca:

A curiosidade como inquietação indagadora, como inclinação ao desenvolvimento de algo, como pergunta verbalizada ou não, como procura de esclarecimento, como sinal de atenção que sugere alerta, faz parte integrante do fenômeno vital. Não haveria criatividade sem a curiosidade que nos move e que nos põe pacientemente impacientes diante do mundo que não fizemos, acrescentando a ele algo que fazemos. (FREIRE, 1996, p.33)

A criatividade nasce ao fomentamos uma ideia, ao buscarmos uma solução. Um dado importante que tive ao trabalhar com os alunos do Teatro Livre é o quão difícil para eles é criar. Muitas vezes, precisamos partir do ócio, do vazio para que algo venha à tona. Em seu livro, Klauss coloca: "Sempre digo em minhas aulas que é preciso dar espaço, um espaço novo em mim para que surjam coisas novas." (2008, p.72) E é justamente nesse entrave que encontrei meus alunos. A contemporaneidade é tão abarrotada de informações, de ideias pré fabricadas, de brinquedos já acabados que percebi em meus alunos uma grande dificuldade em criar. Em determinado momento, foi proposto que eles usassem tecidos para criarem momentaneamente partes de cenário e a imobilidade foi quase total. Os mesmos tecidos que estavam sendo trabalhados durante as aulas não puderam virar nada além de tecidos ou parte do figurino. Diante dessa estagnação me pergunto, o quão grande é o desafio dos novos educadores na inserção das novas tecnologias em suas aulas, e ao mesmo tempo, do resgate em seus alunos da elaboração de seus próprios meios de expressão?

Defendo que arte nas escolas pode ser fator decisivo no desenvolvimento autônomo. O contato com o ensino de artes- que transforma curiosidade em criatividade, propostas em descobertas e valoriza os conteúdos que emergem de cada ser humano - combate a segmentação não só do conhecimento dos conteúdos 
Conceição | Conception

Revista do Programa de Pós-Graduação em Artes da

Cena, Universidade Estadual de Campinas

Performing Arts Graduate Program Journal, University of

Campinas

abordados dentro da sala de aula, mas também a segmentação do próprio ser ao longo de sua jornada.

\section{Considerações Finais}

A partir desses relatos de experiências, vê-se na abordagem tanto freiriana quanto na Educação Somática uma preocupação e disposição quanto ao desenvolvimento da autonomia dos aprendizes no processo de ensino. Para Paulo Freire (1996), a autonomia vai se constituindo com a experiência de inúmeras decisões e escolhas que vão sendo tomadas a frente ao agir perante o direito de liberdade de cada um.

Dessa forma, pensando em um ensino de dança (e porque não no ensino de forma geral) que alcance tais propriedades, um dos caminhos possíveis que encontramos está constituído na conscientização do próprio corpo e do movimento, ou seja, de si próprio sujeito que age num coletivo e possui a possibilidade de transformação desde os seus gestos até o seu entorno. De forma que, o aluno se compreenda, entendendo seu próprio processo de construção do conhecimento em sala de aula, suas dificuldades, e assim possa ter um aprendizado emancipado na sua prática em dança.

Os relatos aqui apresentadas, trouxeram diversas abordagens de métodos de Educação Somática, que se revelaram, como um terrenos férteis para um trabalho educacional que visa para oferecer espaço ao desenvolvimento da autonomia de cada aluno.

Seja em espaços de ensino formal ou não formal, independentemente da técnica somática a qual se utiliza, destaca-se com importância como estas abordagens, à medida que proporcionam aos alunos uma maior conscientização dos seus corpos, possibilitando-lhes ser mais criativos (como foi apresentado em todos os relatos), dispor-se ao contato com o 'outro' e a gradativamente promover a sua 
Conceição | Conception

Revista do Programa de Pós-Graduação em Artes da

Cena, Universidade Estadual de Campinas

Performing Arts Graduate Program Journal, University of

Campinas

autonomia. Também é esta construção a somatória do pensamento da abordagem somática com a escolha e atitude por parte do docente de ser assim, um mediador do conhecimento, abrindo mão do autoritarismo, pois sendo a autonomia algo que se constrói pela consciência, logo só pode vir como uma prática/ação consciente por parte dos docentes.

Outro aspecto comum a todos os quatro licenciados é que eles assumem, cada um à sua maneira, as suas dificuldades e conflitos nesta busca bem como só se interessaram pelo desenvolvimento da autonomia nas suas práticas docentes porque tiveram ao longo do curso de licenciatura em dança da UNICAMP, professores que os influenciaram nisso. Pois:

\begin{abstract}
A autonomia, enquanto amadurecimento do ser para si é processo, é vir a ser. Não ocorre em data marcada. É neste sentido que uma pedagogia da autonomia tem de estar centrada em experiências estimuladoras da decisão e da responsabilidade, vale dizer, em experiência respeitosas da liberdade. (FREIRE, 1996, p.67)
\end{abstract}

\title{
REFERÊNCIAS
}

ALEXANDER, Gerda. Eutonia caminho para a percepção corporal. $2^{a}$ edição brasileira. Tradução de José Luis Mora Fuentes. São Paulo: Martins Fontes Editora, 1991.

BELTRÃO, Bruno. Break dance: Fissão e reação em cadeia. In: Lições de dança 2. Rio de Janeiro: UniverCidade Editora, 2000.

BRANDÃO, Carlos Rodrigues. O que é o método Paulo Freire. $11^{\mathrm{a}}$ edição. São Paulo: Editora Brasiliense, 1981. Coleção Primeiros Passos, nº 38.

FERRACINI, Renato. A presença não é um atributo do Ator. Capítulo de Livro In: Linguagem, Sociedade, Políticas.1ed.Campinas e Pouso Alegre : RG e Univás, 2014, v.1, p. 227-237.

FORTIN, Sylvie. Educação somática: novo ingrediente da formação pratica em dança. Tradução de Márcia Strazzacappa. In: GREINER, Cristine (Org.). Cadernos do GIPE-CIT, n.2. Salvador: UFBA, 1999. p. 40-55. 
Conceição | Conception

Revista do Programa de Pós-Graduação em Artes da

Cena, Universidade Estadual de Campinas

Performing Arts Graduate Program Journal, University of

Campinas

FREIRE, Paulo. Educação e mudança. Editora Paz e terra, 2014.

FREIRE, Paulo. Pedagogia da Autonomia: saberes necessários à prática educativa. São Paulo: Paz \& Terra, 1996.

FREIRE, Paulo - Pedagogia da esperança: Um reencontro com a Pedagogia do Oprimido - Notas: Ana Maria Araújo Freire Rio de Janeiro: Paz e Terra, 1992.

FREIRE, Paulo - Pedagogia do Oprimido, 17ª ed. Rio de Janeiro, Paz e Terra,1987.

GERALDI, Silvia Maria. Representações sobre técnicas para dançar. In: Sigrid Nora (Org.) Húmus 2. Caxias do Sul, RS:Lorigraf, 2007, v.2, p. 75-87.

GERALDI, Silvia Maria. Aprendizagem orgânica: a contribuição do método feldenkrais à educação da dança e do movimento. In: o avesso do avesso do corpo: educação somática como práxis: 97.

MARTINS, Rosana. Hip Hop: o estilo que ninguém segura. Santo André: Prima Linha, 2005.

MILLER, J. A escuta do corpo: sistematização da Técnica Klauss Vianna. São Paulo: Summus, 2007.

MILLER, J. Qual é o corpo que dança?: dança e educação somática para adultos e crianças. São Paulo: Summus, 2012.

VIANNA, K. A dança. São Paulo: Summus, 2008.

MILLER, Jussara - Dança e educação somática: a técnica na cena contemporânea in: O avesso do avesso do corpo - educação somática como práxis /Organizadores: Cristiane Wosniak, Nirvana Marinho- Joinville: Nova Letra, 2011.p. 149-161

NEGRAXA, Thiago. As danças da cultura Hip Hope e Funk Styles. SÃO PAULO: ALL PRINT EDITORA, 2015.

OLIVEIRA, Daniella Machado de; OLIVEIRA, Daniella Machado de. Contribuições para o estudo da adolescência sob a ótica de Winnicott para a Educação. Psicologia em Revista, Belo Horizonte, v. 16, n. 1, p.64-80, abr. 2010

SILVA, A. C. R. Dança de Rua: do ser competitivo ao artista da cena. 15/12/2014. 297p. Dissertação (Mestrado em Artes da Cena) - Universidade Estadual de Campinas. Campinas, SP - 2014. 